\title{
Taking Care of Ourselves: State Citizenship, the Market, and the State
}

\author{
NORMAN R. WILLIAMS*
}

The Constitution forbids the states from discriminating against nonresidents with respect to commercial activities. Yet, courts have allowed states to favor residents over non-residents in a number of ways, such as with respect to public university admissions and government procurement policies. In this Article, the author offers a normative theory and doctrinal framework to reconcile these competing demands of interstate equality and state autonomy. Specifically, states may favor residents with respect to state programs funded by state citizens when such discrimination is necessary to vindicate the citizens' legitimate claim of entitlement to such taxpayer-funded programs. This "investment capture" defense is then applied to the various mechanisms states typically use to favor residents, such as discriminatory tax provisions, government procurement policies, the distribution of government-owned goods and services, and the imposition of so-called "downstream restraints" on private parties who deal with the state.

Several provisions of the Constitution, such as the Dormant Commerce Clause and Privileges and Immunities Clause of Article IV, forbid the states from discriminating against non-residents. Yet at the same time, courts have allowed states to favor residents over non-residents in a number of ways. For instance, states may limit the number of non-residents who may attend state universities and/or require them to pay higher tuition fees; ${ }^{1}$ they can impose preferences for local vendors and products when purchasing goods or services for their own use; ${ }^{2}$ and they can limit the number of hunting licenses available to non-residents. ${ }^{3}$ There are other examples. ${ }^{4}$

* Associate Professor of Law and Director of the Center for Law and Government, Willamette University. A.B., Harvard University; J.D., New York University. Special thanks are owed to Brannon Denning, Joel Goldstein, Hans Linde, and William Nelson for their comments on earlier drafts.

${ }^{1}$ Martinez v. Bynum, 461 U.S. 321, 328 (1983).

2 Smith Setzer \& Sons, Inc. v. S.C. Procurement Review Panel, 20 F.3d 1311, 1320 (4th Cir. 1994); J.F. Shea Co. v. City of Chicago, 992 F.2d 745, 747-49 (7th Cir. 1993).

3 Baldwin v. Fish \& Game Comm'n, 436 U.S. 371,388 (1978).

${ }^{4}$ See, e.g., Reeves, Inc. v. Stake, 447 U.S. 429 (1980) (permitting state to sell stateowned cement only to state residents); Chance Mgmt., Inc. v. South Dakota, 97 F.3d 1107 (8th Cir. 1996) (upholding state's residency requirement for licenses to operate video lottery machines). 
As a doctrinal matter, the Court has attempted to mediate these conflicting demands of interstate equality and state autonomy through the socalled "market participant" exception to the Dormant Commerce Clause, which allows states to favor their residents when the state is acting as a market participant but not market regulator. That distinction in state roles, however, has turned out to be difficult to define and apply. Some state market actions are held invalid, ${ }^{5}$ while other state activities outside the market are declared to be permissible. ${ }^{6}$ Worse, the Court has failed to explain exactly what features render a particular state action participatory rather than regulatory. ${ }^{7}$ As both lower courts and commentators have acknowledged, making sense of the Court's decisions is a daunting task. ${ }^{8}$

This doctrinal disarray has proven to be fertile ground for academic commentators. Defending the Court's decisions, several commentators have argued that a limited market participant doctrine is consistent with the constitutional commitment to a national common market. ${ }^{9}$ Although their analyses differ, they endorse several state activities that favor residents, such as cash subsidies and state procurement preferences. ${ }^{10}$ Meanwhile, other commentators have suggested that theirs is a fool's errand, arguing that there is no justification for allowing states to favor residents or in-state business and that the entire market participant doctrine should be jettisoned. ${ }^{11}$ Indeed, in a notably sectarian vein, Chief Judge Gibbons of the Third Circuit

${ }^{5}$ South-Central Timber Dev., Inc. v. Wunnicke, 467 U.S. 82, 99 (1984) (invalidating contractual condition imposed on sale of state-owned timber).

${ }^{6}$ New Energy Co. of Ind. v. Limbach, 486 U.S. 269, 277 (1988) (suggesting that direct cash subsidy restricted to in-state private businesses is constitutional).

${ }^{7}$ Ethan Yale \& Brian Galle, Muni Bonds and the Commerce Clause after United Haulers, 115 TAX NOTES 1037, 1040 \& n.34 (2007) (noting that market participant exception is "undertheorized").

8 GSW, Inc. v. Long County, 999 F.2d 1508, 1511 (11th Cir. 1993); Swin Res. Sys., Inc. v. Lycoming County, 883 F.2d 245, 249 (3d Cir. 1989); Shell Oil Co. v. City of Santa Monica, 830 F.2d 1052, 1056 (9th Cir. 1987); Donald H. Regan, The Supreme Court and State Protectionism: Making Sense of the Dormant Commerce Clause, 84 MiCH. L. REV. 1091, 1198 (1986).

${ }^{9}$ Dan T. Coenen, Untangling the Market Participant Exemption to the Dormant Commerce Clause, 88 MICH. L. REV. 395 (1989); Mark P. Gergen, The Selfish State and the Market, 66 TEX. L. REV. 1097 (1988); Saul Levmore, Interstate Exploitation and Judicial Intervention, 69 VA. L. REV. 563 (1983); Regan, supra note 8, at 1194; Jonathan D. Varat, State "Citizenship" and Interstate Equality, 48 U. CHI. L. REV. 487, 491 (1981).

10 See, e.g., Dan T. Coenen, Business Subsidies and the Dormant Commerce Clause, 107 YALE L.J. 965, 1053 (1998) (cash subsidies).

11 Hans A. Linde, Constitutional Rights in the Public Sector: Justice Douglas on Liberty in the Welfare State, 40 WASH. L. REV. 10, 67 (1965); Karl Manheim, New-Age Federalism and the Market Participant Doctrine, 22 ARIZ. ST. L.J. 559, 563 (1990). 
dismissed the entire doctrine as a "peculiar eruption of Dixieism," which he analogized to a "disease." 12 Still others have focused their criticism more narrowly on particular forms of state favoritism, such as state business development incentives, arguing that, as to these measures, discrimination against out-of-state interests is impermissible. ${ }^{13}$

The need for a coherent and comprehensive approach to assessing governmental favoritism of in-state residents is manifest. As I argue, considerations of political fairness and public finance efficiency support the notion that states may reserve exclusively to their own citizens the benefit of those programs that are funded by state taxpayers and that cannot be shared equally with non-residents without jeopardizing state citizens' access to such programs. This "investment capture" defense for the market participant exception provides a normative justification for state favoritism in the distribution of many taxpayer-funded goods and services. At the same time, however, the investment capture model forbids discrimination in the distribution of goods and services whose creation state citizens have not funded, such as natural resources like oil or wildlife, or whose distribution to non-residents on equal terms does not interfere with the ability of residents to enjoy such benefits, such as roads or courts.

In this respect, the investment capture model proposed here differs from and is more generous to state authority than the analytical frameworks proffered by other commentators. Professor Jonathan Varat, for example, endorses the notion that citizens have a special claim on those assets that the citizens helped create, but, in his view, that interest only provides a "prima facie" justification for favoring state residents, which justification can be rebutted by non-residents in a variety of circumstances, including (most curiously) when non-residents have a special need for the particular state good. ${ }^{14}$ Similarly, Professor Mark Gergen treats the state interest in favoring its own citizens as secondary to and limited by the requirement that the state provide equal access to resources in the market. ${ }^{15}$ Meanwhile, Professor Dan Coenen and I part company on his claim that the market participant

12 Swin Res., 883 F.2d at 257 (Gibbons, C.J., dissenting).

13 Peter D. Enrich, Saving the States from Themselves: Commerce Clause Constraints on State Tax Incentives for Business, 110 HARV. L. REV. 377 (1996).

14 Varat, supra note 9, at 529-31, 533. One might think that, if an individual has a special need for some state benefit, whatever claim of entitlement that might arise from such need would be more appropriately directed to the person's own state, at least as to goods and service not essential to tourists or visitors to a state.

15 Gergen, supra note 9, at 1112-13. As a result, Professor Gergen condemns downstream restraints and even the Court's decision in Reeves, Inc. v. Stake, 447 U.S. 429 (1980), both of which the investment capture model endorses (at least to a limited extent with regard to the former). See Gergen, supra note 9, at 1142. 
exception rests upon a host of theoretical considerations. ${ }^{16}$ Some of the considerations he identifies do not support the Court's doctrine, while others would entail a global and deleterious revolution in Commerce Clause jurisprudence. These foundational differences lead us to different conclusions regarding what forms of state favoritism are permissible, most notably with respect to the legitimacy of downstream restraints. ${ }^{17}$ To be sure, there is much to admire in their groundbreaking and ambitious works, but the investment capture model offered here provides a more normatively attractive resolution to the constitutional dilemma.

Part I lays out the doctrinal origins of the market participant doctrine and the closely related case law regarding monetary subsidies. Part II canvasses the various theoretical justifications offered by the Court for allowing states to favor state citizens in the distribution of certain state resources, illuminating the flaws in each approach. Part III describes the investment capture defense, demonstrating how considerations of both political justice and economic efficiency support it. This part then develops a doctrinal framework for courts to use in implementing the investment capture model. Building upon this theoretical background, Part IV applies the investment capture model to the various forms of state favoritism, such as subsidies, tax exemptions, and state procurement and sales policies.

\section{The Dormant Commerce Clause And Permissible STATE PROTECTIONISM}

The U.S. Constitution commits the nation to a common market system. Yet, at the same time, the Court has acknowledged two instances in which states may act in a parochial manner, favoring in-state interests at the expense of out-of-state competitors. First, a state may exercise its proprietary power over state-owned resources to favor in-state interests. This is the socalled "market participant" doctrine. Second, a state may subsidize in-state interests, such as by providing a cash grant to in-state businesses.

\section{A. The Market Participant Doctrine}

As the Court has repeatedly admonished, the Dormant Commerce Clause forbids state actions that "discriminate against" interstate commerce, such as by restricting the importation of goods from other states or the exportation of

16 Coenen, supra note 9 , at 419-41.

17 Compare id. at 473 (condemning downstream restraints "as the general rule") and Varat, supra note 9, at 564 (same) with Part IV.C.2, infra (accepting downstream restraints when related to channeling subsidy to residents). 
in-state goods. ${ }^{18}$ Such measures are subject to rigorous scrutiny that amounts to a rule of virtual per se invalidity. ${ }^{19}$ Applying that rule, the Court has invalidated numerous state measures that favor local residents at the expense of out-of-state individuals or businesses. ${ }^{20}$ In so doing, the Court has made real the constitutional promise that, as Justice Jackson put it, "our economic unit is the Nation." 21

In 1976, however, the Court carved an exception to the Dormant Commerce Clause's prohibition on state favoritism for residents. In Hughes v. Alexandria Scrap Corp. ${ }^{22}$ the Court upheld the State of Maryland's discriminatory treatment of out-of-state automobile scrap processors. ${ }^{23}$ In order to encourage the disposal of old, inoperative automobiles (defined as "hulks" by the Maryland statute), Maryland offered a sixteen dollar cash bounty to scrap processors that processed hulks that had been titled in Maryland. Both in-state and out-of-state processors were eligible to participate in the bounty program, but Maryland imposed more onerous paperwork requirements on out-of-state processors. ${ }^{24}$ Maryland's adoption of this discriminatory paperwork requirement served to encourage towing companies and other individuals to take abandoned hulks to Maryland processors. Indeed, one out-of-state processor discovered that the number of hulks deposited with it by unlicensed wreckers declined by over fifty percent after Maryland adopted the discriminatory paperwork requirement. ${ }^{25}$

18 Hughes v. Oklahoma, 441 U.S. 322, 336-37 (1979); Philadelphia v. New Jersey, 437 U.S. 617,628 (1978).

19 The state must demonstrate that its discriminatory regulation serves a legitimate, non-protectionist purpose and that there are no equally effective, non-discriminatory alternatives available to serve such goal. Fort Gratiot Sanitary Landfill, Inc. v. Michigan Dep't of Natural Res., 504 U.S. 353, 359 (1992); Hughes, 441 U.S. at 337. In only one case has the Court concluded that a state made the requisite showing. Maine v. Taylor, 477 U.S. 131, 151-52 (1986) (upholding state ban on importation of live baitfish from other states).

20 Norman R. Williams, The Commerce Clause and the Myth of Dual Federalism, 54 UCLA L. REV. 1847, 1906 n.301 (2007) (collecting cases).

21 H.P. Hood \& Sons v. DuMond, 336 U.S. 525, 537 (1949); see also Richard B. Collins, Economic Union as a Constitutional Value, 63 N.Y.U. L. REV. 43, 45 (1988) ("Economic union was unquestionably a principal aim of the framers.").

22426 U.S. 794 (1976).

23 Id. at 809-10.

24 Both in-state and out-of-state processors had to submit documentation of title to the vehicles in order to receive the bounty, but in-state processors only had to submit a simple "indemnity agreement" signed by the individual who had deposited the vehicle with the processor attesting to his ownership of the vehicle. Out-of-state processors, in contrast, had to submit verifiable title to the vehicle, such as a certificate of title, police certificate, or bill of sale from a police auction. Id. at 801 .

25 Id. at 802 n. 12. 
Upholding the Maryland policy, the Supreme Court ruled that the Maryland policy was immune from Dormant Commerce Clause challenge because it was not regulatory in nature. As a formal matter, towing companies and other individuals could still take Maryland hulks to Virginia processors, though they would not receive the bounty if they did so. As the Court put it, "Maryland has not sought to prohibit the flow of hulks, or to regulate the conditions under which it may occur. Instead, it has entered into the market itself to bid up their price." 26 And, in the Court's view, "[n]othing in the purposes animating the Commerce Clause prohibits a State ... from participating in the market and exercising the right to favor its own citizens over others." 27 In short, the dormant Commerce Clause applied to the state when acting as a market regulator but not as a market participant.

The Court's cursory discussion, however, did little to define the difference between regulatory actions and "market participant" actions. Take, for example, tax exemptions or credits for in-state businesses. On the one hand, they are akin to an impermissible tariff because they distort the competitive relationship between in-state and out-of-state businesses. Yet, tax exemptions or credits could also potentially be viewed (like the subsidy in Alexandria Scrap) as equivalent to a state purchase of the exempted item. Indeed, it is hard to imagine that the result in Alexandria Scrap would have differed had Maryland chosen to provide a sixteen dollar tax credit against the state income tax to in-state processors for each hulk.

Or take state licensing decisions. Much of what state and local governments do today is provide licenses to individuals and businesses to engage in their line of work. ${ }^{28}$ On the one hand, a state's refusal to issue licenses to non-residents could be viewed as regulatory in nature because the state is affecting the composition of the market-denying a license prevents that person or business from engaging in transactions with other individuals just as completely as a statutory prohibition would. ${ }^{29}$ On the other hand, state and local governments often charge fees for licenses, making the issuance of licenses look more like the sale of a government-owned asset and therefore

${ }^{26} \mathrm{Id}$. at 806.

27 Id. at 810 .

${ }^{28}$ Charles A. Reich, The New Property, 73 YALE L.J. 733, 734 (1964).

${ }^{29}$ See, e.g., Conservation Force, Inc. v. Manning, 301 F.3d 985, 993-95 (9th Cir. 2002) (treating discriminatory denial of hunting license as regulatory); USA Recycling, Inc. v. Town of Babylon, 66 F.3d 1272, 1282 (2d Cir. 1995) (holding that town's denial of garbage hauling licenses to all but favored hauler was regulatory action); GSW, Inc. v. Long County, 999 F.2d 1508, 1513 (11th Cir. 1993) (holding that rescission of a contract with a private landfill, which obligated the county to issue a license to the landfill operator, was regulatory action). 
participatory in nature. ${ }^{30}$ The Court's perfunctory analysis in Alexandria Scrap did little to illuminate the proper characterization of these state measures.

In any event, Alexandria Scrap opened the door to state protectionism in the distribution of state assets. In Reeves, Inc. v. Stake, ${ }^{31}$ the Court upheld South Dakota's decision to restrict the sale of cement from its state-owned cement plant exclusively to South Dakota residents. ${ }^{32}$ The South Dakota policy had a devastating effect on an out-of-state construction firm that had traditionally purchased its cement from the South Dakota plant, but that impact was immaterial to the Court. Alexandria Scrap, the Court wrote, had distinguished between "States as market participants and States as market regulators," 33 and, because South Dakota was selling cement that it had manufactured at a state-owned plant, it "unquestionably" fit within the market participant exception. ${ }^{34}$ Likewise, in White v. Massachusetts Council of Construction Employers, Inc., ${ }^{35}$ the Court upheld a City of Boston policy requiring all contractors on city-funded construction projects to employ a specified percentage of city residents on the public works. ${ }^{36}$ Once again, the Court was categorical: because the City was spending its own funds, it was acting as a market participant, not as a market regulator. ${ }^{37}$ The extent of the impact on non-residents was beside the point as a legal matter. ${ }^{38}$

Moreover, White extended the market participant exception in one potentially troubling respect. Unlike the program at issue in Reeves, in which the State itself chose to deal only with in-state residents, the Boston program required city contractors to prefer local residents in their dealings. The City was not itself favoring local businesses; it was requiring the businesses with

30 Cf. Chance Mgmt., Inc. v. South Dakota, 97 F.3d 1107, 1113 (8th Cir. 1996) (holding that State's use of a discriminatory licensing policy when applied to its own activities did not fall outside the market participant exception). Of course, the Privileges and Immunities Clause of Article IV provides some protection against discriminatory licensing denials. See Supreme Court of New Hampshire v. Piper, 470 U.S. 274, 288 (1985) (holding that State's denial of bar licenses to non-residents violated Article IV Privileges \& Immunities Clause). Not all state licenses, however, involve privileges or immunities protected by Article IV. See Baldwin v. Fish \& Game Comm'n, 436 U.S. 371,388 (1978) (holding that State's denial of elk hunting license did not implicate privilege or immunity).

31447 U.S. 429 (1980).

32 Id. at 441.

$33 \mathrm{Id}$. at 436.

34 Id. at 440.

35460 U.S. 204 (1983).

$36 \mathrm{Id}$. at 205-06.

${ }^{37} I d$. at 215.

${ }^{38} \mathrm{Id}$. at 209-10. 
which it dealt to favor local residents. Stated differently, the required favoritism was "downstream." 39

The potential implications for the national economy were enormous. Many companies, including some of the nation's largest, contract with state and local governments. If a state could require as a condition of doing business with the state that all public contractors prefer local residents-such as by hiring only local employees or purchasing goods and services only from local vendors - the state could effectively leverage its purchasing power to achieve protectionist gains for local residents. What the state could not achieve via regulation it could impose by contractual condition.

To be sure, the Court in White acknowledged this danger, but its response was far from reassuring. Although it suggested that there were "some limits" on the ability of a state to impose downstream restraints, the Court declared that formal privity of contract was not among them..$^{40}$ In other words, a state could require other private entities to favor local residents that were not themselves in privity with the state, at least in some undefined instances. In this particular case, the downstream local hiring preference was acceptable, according to the Court, because the favored local workers were "in a substantial if informal sense, working for the city." 41

Just one year after White, however, the Court retreated from its broad endorsement of the validity of downstream restraints. In South-Central Timber Development, Inc. v. Wunnicke, ${ }^{42}$ the Court invalidated the State of Alaska's requirement that private parties that purchased timber from the State must process the timber in-state. ${ }^{43}$ The requirement was imposed by contract only on parties that voluntarily did business with the state by purchasing state-owned timber and was designed to assist Alaska's struggling timber processing industry. ${ }^{44}$ Alaska defended its policy on the ground that White had validated such downstream favoritism. ${ }^{45}$ A plurality of the Court disagreed, holding that the market participant exception did not encompass state efforts to control the activities of purchasers of state-owned goods outside the market in which the state participates. ${ }^{46}$

While White had acknowledged that privity of contract was not necessary to validate a contractually-imposed local preference, the plurality declared that neither was privity sufficient: "Contrary to the State's

39 Coenen, supra note 9 , at 463.

40 White, 460 U.S. at 211 n.7.

${ }^{41} \mathrm{Id}$. (internal quotation marks omitted).

42467 U.S. 82 (1984).

$43 \mathrm{Id}$. at 84 (plurality opinion).

44 Id. at $84-85,88-89$.

45 Id. at 91.

46 Id. at 97-98. 
contention, the doctrine is not carte blanche to impose any conditions that the State has the economic power to dictate, and does not validate any requirement merely because the State imposes it upon someone with whom it is in contractual privity." 47 Rather, a state may require favoritism only "within the market in which it is a participant;" it may not impose conditions "that have a substantial regulatory effect outside of that particular market."48 Indeed, the plurality defended its new limit as necessary to ensure that states did not leverage their control over state-owned resources to require everyone doing business with the state to favor local residents in other aspects of their businesses or lives. ${ }^{49}$

Lastly, in its most recent pronouncements on the market participant exception, the Court has clarified one of the unanswered questions left by Alexandria Scrap-namely, whether discriminatory tax exemptions and credits qualify for the market participant exception. The short answer: they don't. In New Energy Co. of Indiana v. Limbach, ${ }^{50}$ the Court unanimously rejected Ohio's claim that its tax credit for ethanol manufactured in the state fell within the market participant exception. As the Court noted, Ohio had not purchased the ethanol for its own account or use; rather, the tax credit involved the "assessment and computation of taxes-a primeval governmental activity." 51 As such, Ohio's action "cannot plausibly be analogized to the activity of a private purchaser." 52 Similarly, in Camps

47 Id. at 97.

48 Wunnicke, 467 U.S. at 97. As anyone familiar with American antitrust law knows, markets are neither self-defining nor mutually exclusive. Alaska could be said to be participating in the raw timber market, the timber market generally, and/or, most broadly, the wood products market. The validity of the Alaska policy turned upon exactly how the Court defined the relevant market. As one might expect, lower courts have struggled to determine and define the contours of the relevant market in which the state is a participant. Compare Brooks v. Vassar, 462 F.3d 341, 359 (2006) (stating that stateowned liquor stores are participant in the retail wine market), with id. at 363 (Goodwin, J., concurring and dissenting) (stating that state-owned liquor stores are participants only in the wine-and-liquor market).

49 Wunnicke, 467 U.S. at 97-98 (plurality opinion); see also id. at 99 (noting that the State was not "merely choosing its own trading partners" but "attempting to govern the private, separate economic relationships of its trading partners").

50486 U.S. 269,277 (1988).

$51 \mathrm{Id}$.

$52 \mathrm{Id}$. at 278. This brusque rejection of Ohio's claim, however, suggested that the market participant exception did not extend to subsidies of in-state businesses and applied only to state purchases of private goods for its own end use. If so, Alexandria Scrap was wrongly decided. Maryland, after all, had not purchased or taken title to the hulks. Yet, the Court was not prepared to overrule Alexandria Scrap and hold that end use by the state was necessary. Rather, the Court confined Alexandria Scrap largely to its facts, 
Newfound/Owatonna, Inc. v. Town of Harrison, ${ }^{53}$ the Court struck down Maine's discriminatory property tax exemption for charitable organizations. ${ }^{54}$ The Maine law limited the exemption only to charitable organizations that provided services principally for the benefit of in-state residents. Rejecting Maine's defense that it was in effect just purchasing services from the charitable organizations for the benefit of Maine residents, the Court tersely declared that "[a] tax exemption is not the sort of direct state involvement in the market that falls within the market-participation doctrine." 55

\section{B. Subsidies}

Closely related to the 'market participant exception is the issue whether states may offer subsidies to in-state businesses. The Court has assumed but never squarely decided that cash subsidies to in-state businesses are permissible. ${ }^{56}$ Pure cash subsidies, however, are unusual. ${ }^{57}$ Much more common are tax exemptions for favored in-state industries or business development incentives designed to encourage multi-state businesses to open or expand their in-state presence ${ }^{58}$ The latter often come in the form of an

declaring enigmatically that "subsidy programs unlike that of Alexandria Scrap might not be characterized as proprietary." Id. at 277.

53520 U.S. 564 (1997).

$54 \mathrm{Id}$. at $568-71$.

55 Id at 593. Elaborating, the Court observed that accepting such a tenuous link between a tax exemption and the allegedly "purchased" goods or services would effectively swallow the rule against discriminatory tax exemptions since every tax exemption could be defended on this basis. Id. at 594. Moreover, even if some tax exemptions could in principle be analogized to a state purchase of the exempted item, this particular tax exemption could not be so viewed. As the Court pointed out, the breadth of the exemption - the fact that it applied to all charities regardless of what services they provided and regardless of whether such services actually benefited the state even in some indirect fashion-belied the notion that the state was acting in a proprietary role, purchasing services for the state's benefit from the affected charities. Id.

56 Compare New Energy, 486 U.S. at 278 ("Direct subsidization of domestic industry does not ordinarily run afoul of that prohibition [on state action designed to give its residents an advantage in the marketplace].") with W. Lynn Creamery, Inc. v. Healy, 512 U.S. 186, 199 n.15 (1994) (noting that the Court has "never squarely confronted the constitutionality of subsidies"). Of course, Alexandria Scrap provides some support for the constitutionality of such subsidies, but the Court has subsequently construed that decision as approving a subsidy only when it is fair to characterize the state as purchasing some good or service from the subsidized business. See Camps Newfound/Owatonna, 520 U.S. at 592. As such, Alexandria Scrap does not bear upon a pure subsidy in which the state receives no benefit in return.

57 Coenen, supra note 10 , at 995.

${ }^{58}$ See id.; Enrich, supra note 13, at 382-89. 
investment tax credit against the state income tax or a property tax abatement. The central focus of the Court's "subsidy" cases has been to determine whether the particular tax credit or business incentive is more akin to a (theoretically permissible) cash subsidy or (undoubtedly impermissible) tariff. ${ }^{59}$ To date, the Court has yet to uphold a discriminatory tax exemption or credit.

Discriminatory tax exemptions come in three types: those that disfavor out-of-state products, those that disfavor out-of-state businesses, and those that disfavor out-of-state production. ${ }^{60}$ Tax exemptions or credits for in-state goods or services (the first category) present perhaps the easiest case for the Court and are routinely invalidated. Thus, for example, the Court has invalidated Hawaii's wholesale liquor excise tax, which exempted some locally made alcoholic beverages, ${ }^{61}$ and Ohio's motor vehicle fuel sales tax, which granted a credit for ethanol manufactured in the state. ${ }^{62}$ As the Court noted, exempting in-state goods from taxation was equivalent to imposing a tariff on the out-of-state goods that do not receive the tax break. 63

Likewise, the Court has struck down tax exemptions and credits for instate residents (category two). For example, in Camps Newfound/Owatonna, the Court held that Maine's property tax exemption for property owned by charities violated the Dormant Commerce Clause because the exemption was available only to charities that primarily served state citizens. ${ }^{64}$ Because the practical effect of the measure was to penalize charitable organizations that served out-of-state residents, the Court viewed the discriminatory tax exemption as akin to a tariff, this time on out-of-state residents seeking the assistance of in-state charities. ${ }^{65}$ Moreover, the Court specifically rejected Maine's argument that the tax exemption was equivalent to a permissible cash subsidy to charities that serviced Maine residents. Much like it had done with respect to Maine's market participant defense, the Court denied that a tax exemption was analogous as a legal matter to a subsidy. ${ }^{66}$

59 See, e.g., W. Lynn Creamery, 512 U.S. at 194-95 (treating subsidy to in-state dairy farmers funded by milk tax as akin to tariff).

${ }^{60}$ Michael J. Graetz \& Alvin C. Warren, Jr., Income Tax Discrimination and the Political and Economic Integration of Europe, 115 YALE L. J. 1186, 1195 (2006).

61 Bacchus Imports, Ltd. v. Dias, 468 U.S. 263, 273 (1984).

62 New Energy Co. of Ind. v. Limbach, 486 U.S. 269, 280 (1988).

63 Id. at 276.

64 Camps Newfound/Owatonna, Inc. v. Town of Harrison, 520 U.S. 564, 575, 58788 (1997).

$65 \mathrm{Id}$. at $580-81$.

${ }^{66} \mathrm{Id}$. at $590-91$ (citing Walz v. Tax Comm'n of the City of New York, 397 U.S. 664, 675 (1970) and New Energy, 486 U.S. at 278); see also id. at 591 (noting that distinction between exemption and subsidy "is supported by scholarly commentary as well as precedent"). 
Discriminatory tax breaks for companies that open or expand their instate activities (category three) present the most difficult case for the Court. Yet, even here, the Court has been hostile to tax measures that favor in-state business operations over comparable out-of-state activities. Thus, for example, the Court invalidated New York's securities transfer tax, which applied a lower tax rate to transfers made through in-state stock exchanges, ${ }^{67}$ and New York's tax credit for Domestic International Sales Corporations, which applied only to the gross receipts from export products shipped from New York and not other states. ${ }^{68}$ As the Court noted, reducing the tax burden on in-state activities was akin to increasing the tax burden on out-of-state activities. ${ }^{69}$

Lastly, even a pure cash subsidy that is funded by a tax on the items produced by the subsidized industry has run afoul of the Court's prohibition on protectionism. To assist its dairy farmers, the State of Massachusetts imposed a tax on the purchase of milk by Massachusetts milk dealers. The tax was non-discriminatory; it applied to all milk regardless of origin. The proceeds of the tax were deposited in a special fund, which was then disbursed to Massachusetts dairy farmers. In West Lynn Creamery, Inc. v. Healy, ${ }^{70}$ the Supreme Court invalidated the Massachusetts program. ${ }^{71}$ The Court held that, because all of the proceeds of the tax went to in-state dairy farmers, the tax was effectively imposed only on out-of-state milk and was therefore "[1]ike an ordinary tariff." 72

West Lynn Creamery's condemnation of the Massachusetts tax-andsubsidy program, however, potentially called into question whether any subsidy would survive constitutional scrutiny. As Justice Scalia observed, every cash subsidy reduces the net tax burden of the benefited local industry and therefore assists such businesses vis-à-vis their out-of-state competitors in a way that is functionally equivalent to a tariff on the products of their outof-state competitors. ${ }^{73}$ Attempting to address this concern, the Court responded that the key feature condemning the Massachusetts program was that the subsidy was funded exclusively by a tax on milk. According to the Court, a pure subsidy funded out of general revenue would not cause constitutional concern because such a subsidy "imposes no burden on interstate commerce, but merely assists local business."74 As Professor

${ }^{67}$ Boston Stock Exch. v. State Tax Comm'n, 429 U.S. 318,336 (1977).

68 Westinghouse Elec. Corp. v. Tully, 466 U.S. 388, 407 (1984).

69 Id. at 404-05.

70512 U.S. 186 (1994).

71 Id. at 194.

72 Id.

${ }^{73} \mathrm{Id}$. at 208-09 (Scalia, J., concurring in the judgment).

$74 \mathrm{Id}$. at 199. 
Coenen has observed, however, that was hardly an answer at all since every benefit to in-state industry will feel like a burden to their out-of-state competitors. ${ }^{75}$

Justice Scalia, who concurred in the Court's judgment, took a different, more formal approach to distinguishing the Massachusetts program from other, permissible subsidies. As Justice Scalia noted, Massachusetts could accomplish its desired aim of benefiting in-state dairy farmers through one of four different types of measures: (1) a tariff on out-of-state milk; (2) a nondiscriminatory tax on milk that is coupled with an exemption or credit for instate milk; (3) a non-discriminatory tax on milk, the proceeds of which "are placed into a segregated fund, which is disbursed as 'rebates' or 'subsidies' to in-state members of the industry;" or, (4) a cash subsidy to in-state farmers funded from the state's general revenue. ${ }^{76}$ According to Scalia, the first two types of measures were clearly unconstitutional, while the last option of a pure subsidy funded from general revenues was permissible. ${ }^{77}$ That left the issue of a subsidy from a segregated fund, like the Massachusetts program. For Justice Scalia, the segregated fund subsidy was more akin to the impermissible discriminatory tax rebate than the permissible general fund subsidy:

The only difference between methodology (2) (discriminatory "exemption" from nondiscriminatory tax) and methodology (3) (discriminatory refund of nondiscriminatory tax) is that the money is taken and returned rather than simply left with the favored in-state taxpayer in the first place. The difference between (3) and (4), on the other hand, is the difference between assisting in-state industry through discriminatory taxation and assisting instate industry by other means.

I would therefore allow a State to subsidize its domestic industry so long as it does so from nondiscriminatory taxes that go into the State's general revenue fund. ${ }^{78}$

Drawing the line between subsidies drawn from a segregated fund and those funded from the general treasury was, in Scalia's view, "a clear, rational line."79

75 Coenen, supra note 10, at 1009; see also W. Lynn Creamery, 512 U.S. at 208-09 (Scalia, J., concurring in the judgment) (noting that every subsidy for in-state businesses harms out-of-state businesses by neutralizing their competitive advantages).

76 W. Lynn Creamery, 512 U.S. at 210 (Scalia, J., concurring in the judgment).

$77 \mathrm{Id}$. at 211. Indeed, Justice Scalia correctly observed that Alexandria Scrap had upheld just such a measure. Id.

78 Id.

${ }^{79} \mathrm{Id}$. at 212. 
As the foregoing discussion has revealed, the development of the market participant doctrine has not been accompanied or supported by a grand theory that explains the Court's decisions and provides guidance to state and local lawmakers. What little normative discussion the Court has offered has been strikingly unsophisticated and incapable of bearing the decisional weight placed upon it. Indeed, it is perhaps for this reason that so many of the Court's rulings in this area rest on the identification of the appropriate, precedential analogy: Whether a particular measure survives judicial review turns on whether the measure is viewed as more like a tariff or more like a subsidy, whether it is perceived as more like the measure invalidated in Case A or like the measure upheld in Case B. Such analogical reasoning and fealty to precedent is not to be dismissed, but it cannot substitute wholly for a normative theory to explain why discriminatory state action in any form is permissible and, if so, to what extent. Absent such a theory, the adjudication of discriminatory measures will devolve into an arid, intellectual exercise in which a measure's validity is determined by its similarity to other measures previously upheld or invalidated by the Court. It is to the search for such theory that we next turn.

\section{The COURT's JustificAtions For State ProteCtIonisM}

The market participant exception is a doctrine in search of a theory. As others have noted, different normative justifications for the doctrine have been offered by the Court at different times. ${ }^{80}$ As this Part illuminates, however, none of the proffered theories can both justify the doctrine and account for its doctrinal limitations.

\section{A. Textual Formalism}

As a textual matter, the Commerce Clause empowers Congress to regulate interstate commerce. One might seize upon the word "regulate" and argue that the Dormant Commerce Clause therefore only forbids the adoption of state measures that can be said to regulate interstate commerce. On this view, other forms of state action are therefore immune from constitutional challenge as a matter of fidelity to the constitutional text. ${ }^{81}$ Indeed, in New Energy, the Court appeared to embrace this view, observing that "[ $t]$ he Commerce Clause does not prohibit all state action designed to give its

${ }^{80}$ Manheim, supra note 11 , at 580.

81 Coenen, supra note 9 , at 436-37. 
residents an advantage in the marketplace, but only action of that description in connection with the State's regulation of interstate commerce." 82

Of all of the defenses of the market participant doctrine, this is among the weakest. As an initial matter, the rigid obeisance to constitutional text upon which this argument rests is inconsistent with the existence of the Dormant Commerce Clause itself, which-as its critics have repeatedly emphasized ${ }^{83}$ - does not appear in the constitutional document. Stated differently, one cannot accept the atextual Dormant Commerce Clause but then demand an exception be made to it in the name of the constitutional text. At the very least, such facial inconsistency in interpretive methodology demands an explanation why the text should be given weight with respect to some parts of the Dormant Commerce Clause doctrine and not others. Absent such an accounting, the literalism of this argument resembles self-serving cherry-picking of interpretive methodologies.

In any event, this textualist defense suffers from a fatal flaw on the merits: it proves far too much. Limiting the Dormant Commerce Clause only to those state measures that "regulate" interstate commerce would necessarily mean that state taxes are therefore immune from Dormant Commerce Clause attack because taxes are not regulations. ${ }^{84}$ Of course, as a normative matter, it would make no sense to prohibit states from adopting protectionist regulations but then allow them to adopt discriminatory taxes, such as tariffs. ${ }^{85}$ And, as a matter of Supreme Court doctrine, it is far too late in the day to argue that the Court should confine its review only to state regulations. The Supreme Court has applied the Dormant Commerce Clause to state taxes in numerous cases for well over a century and a half. Indeed, the very first case in which the Supreme Court invalidated a state measure on the basis of the Dormant Commerce Clause involved a tax. ${ }^{86}$

82 New Energy, 486 U.S. at 278 (emphasis removed).

83 See, e.g., Camps Newfound/Owatonna, Inc. v. Town of Harrison, Me., 520 U.S. 564, 610 (1997) (Thomas, J., dissenting); General Motors Corp. v. Tracy, 519 U.S. 278, 312 (1997) (Scalia, J., concurring); Julian N. Eule, Laying the Dormant Commerce Clause to Rest, 91 YALE L.J. 425, 429-30 (1982); Martin H. Redish \& Shane V. Nugent, The Dormant Commerce Clause and the Constitutional Balance of Federalism, 1987 DUKE L.J. 569, 571, 583.

84 The fact that the congressional power to lay taxes and to regulate commerce are granted in different clauses testifies to this difference. See U.S. CONST. art. I, $\S 8$, cls. 1,3 .

85 Nor would the Import-Export Clause of Article I prevent such measures. The Supreme Court has limited that Clause exclusively to tariffs on foreign goods. Woodruff v. Parham, 75 U.S. (8 Wall.) 123, 133-34 (1868); see also Camps Newfound/Owatonna, 520 U.S. at 635-36 (Thomas, J., dissenting) (urging reinterpretation of Import-Export Clause to cover tariffs on out-of-state goods).

86 See The Passenger Cases, 48 U.S. (7 How.) 283, 283-84 (1849). 
Perhaps one could attempt to deflect part of this challenge by contending that some taxes are regulatory in nature (and would therefore be unconstitutional on this view). Admittedly, there was a time prior to the New Deal when the Supreme Court invalidated several federal taxes as beyond Congress's taxation power because, in the Court's view, they were not truly taxes but instead regulations of commerce beyond Congress's authority to adopt ${ }^{87}$ Even at the time, however, the Court acknowledged the difficulty of the task, ${ }^{88}$ and, following the New Deal, the Court abandoned the effort because, as the Court recognized, there was no principled basis by which to distinguish between true taxes, whatever they were, and regulatory taxes. ${ }^{89}$

That history should provide a cautionary lesson for those who would urge the Court to resurrect that jurisprudence for service in reviewing state taxes. The most obvious candidate criterion for distinguishing between regulations and taxes-taxes raise revenue, regulations alter behaviorfounders upon the fact that all taxes alter behavior to some extent.$^{90}$ On this view, all taxes are regulations-a position that is inconsistent with the constitutional text (which, after all, is the centerpiece of this formalist defense of the market participant doctrine). At the same time and even more problematically, some of the very measures protected by the market participant exception also alter behavior and therefore could be said to be regulatory in nature..$^{11}$ In short, there is no sound textual basis for treating taxes but not proprietary actions as constitutionally equivalent to regulations.

Lastly, the textualist defense of the market participant exception cannot explain Wunnicke's mind-your-own-market limitation on the doctrine. Alaska had not adopted a regulation but rather had simply disposed of a state-owned resource by contract. True, Alaska attached the timber processing condition so as to alter the purchasers' behavior after they took possession of the timber, but the affected individuals had voluntarily agreed to that condition by purchasing the timber. It would be strange to label a private party's voluntary agreement to perform certain tasks pursuant to its contract with the state as an act of regulation by the state. Indeed, White, in which the Court upheld just such a voluntarily assumed condition as within

${ }^{87}$ See Bailey v. Drexel Furniture Co., 259 U.S. 20, 38 (1922).

$88 \mathrm{Id}$.

${ }^{89}$ United States v. Kahriger, 345 U.S. 22, 28 (1953).

${ }^{90} \mathrm{Id}$. (noting that a federal tax does not cease to be a tax "merely because it discourages or deters the activities taxed"). Indeed, some tax provisions are intended to and profoundly do alter behavior. See, e.g., 26 U.S.C. $\$ 401(k)$ (2000) (providing tax exemption for retirement contributions so as to encourage retirement savings).

${ }^{91}$ For example, the Boston requirement that at least half of the contractor's workforce be local residents, which was upheld in White, would surely encourage some contractors to hire more Boston residents than they otherwise would have. 
the market participant exception, implicitly rejected such a view. Moreover, recall that it was not the fact that Alaska was "regulating" the timber purchaser's behavior that invalidated the measure. Rather, it was the fact that Alaska was controlling the behavior of the purchaser in another market. Perhaps Wunnicke was rightly decided, but, if so, it is not because the constitutional language "to regulate" distinguishes between intra-market and extra-market conditions on the sale of timber. In short, the constitutional language simply cannot bear the weight placed upon it by proponents of this textualist defense.

\section{B. Economic Functionalism}

Perhaps one of the most often proffered defenses of the market participant doctrine is the notion that state proprietary actions do not economically harm interstate commerce in the same way or to the same degree as the adoption of regulations or the imposition of taxes do. The Court invoked just such an idea in Alexandria Scrap, suggesting that Maryland's automobile hulk subsidy had not burdened interstate commerce. ${ }^{92}$ Likewise, one Court of Appeals has defended the market participant exception on the ground that discriminatory market actions do not "establish barriers within the general market framework that impede interstate commerce."93

As others have noted, ${ }^{94}$ this defense of the market participant exception is poppycock. As an economic matter, there is no qualitative difference between a tariff on goods produced by out-of-state manufacturers and a subsidy to in-state manufacturers; both will distort the competitive relationship between in-state and out-of-state firms by providing assistance to local businesses. ${ }^{95}$ Nor is there any necessary quantitative difference in the impact of a tariff versus that of a subsidy; indeed, a large subsidy to in-state firms may be more distortionary and deleterious to interstate competition

92 Hughes v. Alexandria Scrap Corp. v., 426 U.S. 794, 808 (1976) ("But until today the Court has not been asked to hold that the entry by the State itself into the market as a purchaser, in effect, of a potential article of interstate commerce creates a burden upon that commerce if the State restricts its trade to its own citizens or businesses within the State."); see also Levmore, supra note 9, at 584.

93 Smith Setzer \& Sons, Inc. v. South Carolina Procurement Review Panel, 20 F.3d 1311, 1318 (4th Cir. 1994); see also Regan, supra note 8, at 1194.

94 Coenen, supra note 9, at 415; Enrich, supra note 13, at 445; Manheim, supra note 11 , at 592.

95 Coenen, supra note 10, at 971; Gergen, supra note 9, at 1135; Varat, supra note 9, at 544; Edward A. Zelinsky, Are Tax Benefits Constitutionally Equivalent to Direct Expenditures, 112 HARV. L. REV. 379, 391 (1998). 
than a small tariff on out-of-state goods. ${ }^{96}$ It is for this reason that international trade agreements typically limit the authority of national governments to offer subsidies to domestic industry. ${ }^{97}$ Indeed, in Alexandria Scrap, even the Court acknowledged the practical effect of the measure was to drastically curtail the number of Maryland hulks processed out of state. ${ }^{98}$ In short, whether a state attempts to protect its local industry from outside competition by levying a tariff on out-of-state goods, providing a cash subsidy to its local industry, or agreeing to purchase goods only from local industry at higher-than-market prices, the effect on out-of-state industry is the same-a loss of competitive position vis-à-vis in-state businesses.

Perhaps one could attempt to rehabilitate this defense of the market participant exception by arguing that subsidies and other analogous forms of state action impose burdens on interstate commerce that are qualitatively different from those imposed by tariffs and discriminatory regulations. Justice Stevens, in his concurring opinion in Alexandria Scrap, attempted just such an argumentative move. According to Stevens, it was appropriate to distinguish between "commerce which flourishes in a free market and commerce which owes its existence to a state subsidy program." 99 In Stevens' view, the Maryland bounty program created a market for hulks that would not otherwise exist, and, therefore, Maryland's decision to limit its subsidy to in-state interests did not burden out-of-state processors in the sense of taking away something they otherwise would have had. Maryland's refusal to extend the subsidy to out-of-state business left them no worse off than had Maryland failed to adopt any subsidy program at all-a policy choice that would obviously not violate the Dormant Commerce Clause. ${ }^{100}$

Justice Stevens' approach, however, rests on the discredited distinction between a burden imposed and a benefit withheld. ${ }^{101}$ Even if out-of-state businesses do not lose any business that they already possessed, their inability to participate in the new, subsidized market is surely a burden to them in some sense. ${ }^{102}$ Moreover, the subsidy is highly likely to generate

96 Coenen, supra note 10, at 1009; cf. New Energy Co. of Indiana v. Limbach, 486 U.S. 269, 278 (1988) (noting that cash subsidy is "no less effective [than a discriminatory tariff] in conferring a commercial advantage over out-of-state competitors").

97 Agreement on Subsidies and Countervailing Measures, Apr. 15, 1994, The WTO Agreement, Annex 1A, Results of the Uruguay Round (prohibiting subsidies that cause "injury to the domestic industry of another Member"); see also Coenen, supra note 10, at 971.

\footnotetext{
98 Hughes v. Alexandria Scrap Corp., 426 U.S. 794, 806 \& n.15 (1976).

${ }^{99}$ Id. at 815 (Stevens, J., concurring).

$100 I d$. at 816.

101 Metro. Life Ins. v. Ward, 470 U.S. 869, 882 (1985) (rejecting distinction).

102 Coenen, supra note 10 , at 1009.
} 
spillover effects, allowing the subsidized in-state businesses to develop new business or marketing practices that can be used against their out-of-state competitors in other markets. And, of course, the mere fact that the in-state businesses are being propped up is something of a harm to their out-of-state competitors, which might have otherwise succeeded in driving the in-state companies out of business.

More fundamentally, even if the distinction between a burden imposed and benefit withheld were a coherent or stable one, the fact that a measure does not burden commerce in the way suggested by Justice Stevens does not distinguish subsidies like that in Alexandria Scrap from other, clearly invalid forms of state protectionism, such as tariffs and embargoes. Under Justice Stevens' approach, tariffs and embargoes would be permissible whenever the state could plausibly maintain that out-of-state businesses were not made worse off. The Court, however, has properly rejected such a defense to protectionist taxes and regulations. ${ }^{103}$ In short, if there is a difference between permissible and impermissible forms of state favoritism, it is not because some types of measures affect interstate commerce differently or to a less substantial degree than state taxes or regulations do.

\section{Sovereignty}

A different justification for the market participant exception roots itself in the special status of states in our federal system. As the Court put it in Reeves, considerations of state sovereignty and the "role of each State as guardian and trustee for its people" lend credence to the doctrine. ${ }^{104}$

Of course, merely pointing to the special status of states in our constitutional system is insufficient by itself to differentiate the states' proprietary powers from their regulatory and taxation powers. As Professor Varat has rightly observed, the states act as guardians for their people in every aspect of state activity, not just their proprietary ones. ${ }^{105}$ Thus, were it true that considerations of state sovereignty justify the state in engaging in discriminatory market transactions, they would also presumably justify the state in adopting discriminatory regulations and taxes.

For this reason, proponents of this defense argue in a more limited fashion that state market transactions are special-that the state has a more important sovereign interest in the disposition of state-owned resources than

103 See, e.g., Bacchus Imports, Ltd. v. Diaz, 468 U.S. 263, 269 (1984).

104 Reeves, Inc. v. Stake, 447 U.S. 429, 438 (1980) (citation and internal quotation marks omitted).

105 Varat, supra note 9, at 506. 
in the regulation or taxation of private individuals. ${ }^{106}$ Thus, as Professor Coenen has argued, it is "a greater intrusion on state autonomy to restrict a state's use of its own tangible resources than to cabin its otherwise limitless power to coerce through government fiat."107

That assertion, however, is more easily stated than explained. In fact, subsequent to Reeves, the Court retreated from the notion that state proprietary actions possess a special constitutional status, at least one sufficient to insulate them from federal regulation. In two landmark cases from the 1990s, the Court ruled that the Tenth Amendment-which deals with claims of state sovereignty-forbids Congress from commandeering state legislative or executive officials in the service of federal regulatory ends. ${ }^{108}$ Yet, when Congress regulated a state's use of its own database, barring the state from selling the information contained in the state database, the Court held in Reno v. Condon ${ }^{109}$ that there was no violation of state sovereignty. 110 Upholding the federal Driver's Privacy Protection Act (DPPA), the Court declared "the DPPA does not require the States in their sovereign capacity to regulate their own citizens. The DPPA regulates the States as the owners of data bases." 111 Admittedly, Reno does not say that the states' proprietary powers are unimportant or may be commandeered in the service of federal regulatory ends, but it does hold that federal interference with state choices over how to dispose of state-owned resources does not raise any special constitutional concerns-a view at odds with that of the sovereignty defense.

Of course, one might respond that the Court got it wrong in Condon, but that would illuminate a more profound, normative difficulty with the argument that the states' proprietary powers are more important to them than their regulatory and taxation powers: There is no objective basis, at least as a matter of federal law, ${ }^{112}$ for creating a hierarchy of state functions and

106 Smith Setzer \& Sons, Inc. v. South Carolina Procurement Review Panel, 20 F.3d 1311,1321 (4th Cir. 1994) (arguing that barring discrimination in allocation of state resources would impede resident's receipt of benefits "at the core of state-governmental responsibility").

107 Coenen, supra note 9, at 427.

108 New York v. United States, 505 U.S. 144, 161 (1992); Printz v. United States, 521 U.S. 898, 933 (1997).

109528 U.S. $141(2000)$.

110 Id. at 143 .

111 Id. at 151 .

112 State law, of course, may draw such distinctions, but, notably, many states often treat regulatory and taxation powers as especially intertwined with state sovereignty. For example, while the management of state-owned resources can often be delegated or outsourced to private companies, state constitutions or statutes often prevent states from delegating their regulatory or taxation powers to private individuals. Of course, state law 
powers. States "own" their regulatory and taxation powers as much as their proprietary resources. Declaring that the former are less important (or less bound up with the states' status as sovereign entities) than the latter seems to rest upon strikingly subjective considerations of the sort that the federal courts must eschew.

In this vein, it is useful to recall the demise of the "integral governmental functions" rule of National League of Cities v. Usery. ${ }^{113}$ There, the Court held that Congress's commerce power did not include the authority to regulate "integral governmental functions" of the states. ${ }^{114}$ The Court, however, subsequently overruled Usery in Garcia v. San Antonio Metropolitan Transportation Authority, ${ }^{15}$ holding in part that the integral governmental functions rule was both unworkable in practice and unsound in principle. ${ }^{16}$ As the Court explained, the line distinguishing between integral or traditional governmental functions and other state governmental functions was "elusive at best." 117 The Court particularly worried that the integral government functions rule required unelected federal judges to make unprincipled decisions as to which state functions were sufficiently important to warrant immunity from federal regulation. ${ }^{118}$

Strictly speaking, Garcia does not address the distinction between state proprietary and regulatory activities. ${ }^{119}$ What Garcia does speak to, however, is the danger of attempting to identify those aspects of state sovereignty deserving of constitutional protection. And that danger exists equally whether a court is being asked to decide that state proprietary powers are essential to state sovereignty or that operating an airport is an integral governmental function. ${ }^{120}$

does not control the interpretation of the Commerce Clause, but it is at least telling that many states view their regulatory and taxation powers as more intimately bound up with their status as sovereign governments than their proprietary powers.

113426 U.S. 833, 851 (1976).

$114 \mathrm{Id}$.

115469 U.S. 528 (1985).

116 Id. at $546-57$.

${ }^{117}$ Id. at 539.

${ }^{118}$ Id. at 545-46.

119 See Swin Res. Sys., Inc. v. Lycoming County, 883 F.2d 245, 255 (3d Cir. 1989) (concluding that Garcia did not undermine market participant exception). But see id. at 260-61 (Gibbons, C.J., dissenting) (arguing that Garcia overturned market participant doctrine); Manheim, supra note 11, at 611 (same).

120 Garcia, 469 U.S. at 538 (citing Amersbach v. City of Cleveland, 598 F.2d 1033, 1037-38 (6th Cir. 1979)). Professor Coenen views Garcia as inapposite additionally because the problem with the integral governmental function rule was that it denied Congress the ability to regulate certain aspects of state behavior, whereas the market participant exception still leaves Congress with the authority to regulate state proprietary 
Lastly, if true, the sovereignty defense would call into question Congress's affirmative power under the Commerce Clause to regulate state proprietary activities. If the states' interest in controlling state-owned resources is so intimately bound up with their identity and status as separate sovereigns as to make the Dormant Commerce Clause inapplicable, it must also be true that such sovereignty interest is sufficiently important that Congress may not overrule it via its affirmative commerce power. As a doctrinal matter, the Court expressly rejected that latter suggestion in Condon, but, more importantly, the mere suggestion that such activities would be exempt from federal regulations points to the danger of embracing the sovereignty defense. States no doubt view their decisions about how to manage and dispose of state-owned resources as vitally important, but that does not justify exempting such decisions from either congressional regulation or constitutional scrutiny.

\section{Equal Treatment with Private Entities}

In contrast to the sovereignty defense, which emphasizes the states' unique status, this equal treatment defense minimizes the difference between states and private entities. According to this justification, it is fair to allow states to favor in-state businesses in their proprietary dealings because private businesses can choose with whom they wish to deal. On this view, it is unfair to states to apply the Dormant Commerce Clause to their proprietary trading relationships because private businesses engaged in similar activities are not similarly constrained by the doctrine. As the Court put it in Reeves, "state proprietary activities may be, and often are, burdened with the same restrictions imposed on private market participants. Evenhandedness suggests that, when acting as proprietors, States should similarly share existing freedoms from federal constraints, including the inherent limits of

activities. See Dan T. Coenen, The Impact of the Garcia Decision on the Market Participant Exception to the Dormant Commerce Clause, 1995 U. ILL. L. REV. 727, 75356 (1995). As discussed infra, the sovereignty defense may in fact preclude Congress from regulating state proprietary activities, thereby raising for the market participant exception the same counter-majoritarian problem that $U$ sery presented. Even if that is not the case, though, the fact that Congress could prohibit certain particularly noxious forms of state discrimination in the distribution of state resources does not mean that the Court should be free to circumscribe the scope of the Dormant Commerce Clause based on its own views as to what state powers are truly essential to statehood. Stated differently, just because Congress could theoretically correct the Court's error does not license the Court to make the error in the first place. 
the Commerce Clause." 121 This rationale has drawn considerable and widespread support. ${ }^{122}$

Once again, the seeming attractiveness of this justification evaporates upon closer inspection. To begin with, the mere fact that private businesses need not comply with the Dormant Commerce Clause does not provide a sufficient basis for exempting states in their proprietary capacity from its strictures. Private businesses are not subject to the Equal Protection Clause, Due Process Clause, or other constitutional provisions, ${ }^{123}$ yet no one would suggest that states, when they act in a proprietary capacity, should be exempt from these constitutional restrictions too. The states are sovereign governmental entities possessing enormous power that can be abused if not checked. As Hans Linde has aptly observed, "[w]hen government serves, owns, manages, sells, it yet remains government, the object of constitutional law."124 For that reason, it is not "unfair" to require states to comply with the Constitution, even if private businesses need not do so. ${ }^{125}$ Indeed, any state demand to be exempted from constitutional constraints as a matter of equal treatment with private businesses would come with ill-grace in light of the fact that states often demand and receive exemptions from federal statutory restrictions that apply to private businesses. ${ }^{126}$

In response, one might argue that even if states are not entitled to a general exemption from constitutional constraints when they act in a proprietary capacity, they should receive an exemption solely from the Dormant Commerce Clause. On this view, the Dormant Commerce Clause differs from and is less necessary than other constitutional constraints on state proprietary powers. ${ }^{127}$ It is not clear exactly why that might be true, but

121 Reeves, Inc. v. Stake, 447 U.S. 429, 438 (1980).

122 GSW, Inc. v. Long County, 999 F.2d 1508, 1513-14 (11 th Cir. 1993); J.F. Shea Co. v. City of Chicago, 992 F.2d 745, 749 (7th Cir. 1993); Yale \& Galle, supra note 7, at 1040.

123 See Civil Rights Cases, 109 U.S. 3, 11 (1883) (holding that the Fourteenth Amendment does not apply to private action). The one exception is the Thirteenth Amendment, which prohibits slavery by private parties as well as states. U.S. CONST. amend. XIII.

${ }^{124}$ Hans Linde, Justice Douglas on Freedom in the Welfare State: Constitutional Rights in the Public Sector, 39 WASH. L. REV. 4, 8 (1964).

125 See Varat, supra note 9, at 506.

126 The most salient example is the Sherman Antitrust Act. See Parker v. Brown, 317 U.S. 341, 351 (1943).

127 See Coenen, supra note 9, at $421 \&$ nn. 166-67 (suggesting that the Dormant Commerce Clause may impose less of a restriction on state proprietary action than the Equal Protection Clause). At the same time, it is not clear that Professor Coenen fully believes in this defense. He concedes that the defense suffers from several difficulties and ultimately declares it to be of "limited significance." Id. at 421 . 
presumably part of the answer consists of the notion that there is less or no need for the Dormant Commerce Clause when states are acting in a proprietary capacity-that states can be trusted to act in a fashion consistent with the values underlying the Dormant Commerce Clause because, at least in their proprietary capacity, they will act just like private businesses.

The problem with this more limited variant of the fairness defense is that states are not just like private businesses when they engage in market transactions. ${ }^{128}$ Private businesses, because they are typically for-profit entities, have no incentive to discriminate against out-of-state individuals; indeed, most private businesses desire to sell their goods to out-of-state customers or to purchase needed supplies from out-of-state sources. It is for that reason that private businesses often go to the substantial expense of challenging state regulations and taxes that inhibit such interstate exchanges. ${ }^{129}$

States and local governments, in contrast, do not respond to the profit motive. At times, states demonstrate a shocking insensitivity to cost concerns, such as when they purchase goods from in-state vendors at inflated prices much higher than that offered by out-of-state sources. ${ }^{130}$ Rather, states respond to non-market, political pressures, ${ }^{131}$ and, because state political systems are far more sensitive to in-state residents (because they, unlike outof-state individuals, elect the state officials), it is no surprise that states act in a parochial fashion even in their proprietary dealings. Indeed, the proof is in the pudding: no private cement producer, for example, would have taken the action South Dakota did in Reeves, refusing to sell except to in-state customers at prices lower than that out-of-state purchasers were willing to pay. It was only because the South Dakota State Cement Commission and other elected South Dakota officials stood to reap political benefits from the discriminatory policy that South Dakota adopted it.

In short, even in their proprietary roles-perhaps especially so-states are likely to act in a parochial fashion. As such, there is no unfairness in applying the Dormant Commerce Clause to states, even though private businesses need not comply with its strictures. Businesses are businesses, and states are states.

128 Reeves, Inc. v. Stake, 447 U.S. 429, 450 (1980) (Powell, J., dissenting); Coenen, supra note 9, at 421; Varat, supra note 9, at 506; see also United Haulers Ass'n v. Oneida-Herkimer Solid Waste Mgmt. Auth., 127 S. Ct. 1786, 1795-96 (2007) (holding that public enterprises are not similarly situated to private enterprises).

129 See, e.g., Hughes, 441 U.S. at 324; Fort Gratiot, 504 U.S. at 359.

130 See, e.g., S.C. CODE ANN. §11-35-1524 (Law. Co-op. 1976 \& Supp. 2007) (providing that state and local governments must purchase in-state goods so long as cost is no more than seven percent higher than comparable out-of-state goods).

131 Reeves, 447 U.S. at 450 (Powell, J., dissenting); Varat, supra note 9, at 506. 
In sum, none of the theories proffered by the Court withstands scrutiny. Indeed, the mere fact that the Court has offered so many and has refused to settle on one or more of these justifications suggests that the Court itself has reservations about the merits of them. In any event, the weakness of the Court's proffered theories does not mean that the market participant doctrine is illegitimate; it only means that the justification for the doctrine must be found elsewhere.

\section{THE INVESTMENT CAPTURE MODEL}

Although the Court has not offered a normatively attractive justification for the market participant doctrine, there is one available: the investment capture theory. According to this defense, it is permissible for states to reserve to their citizens those goods and services created by the state because the citizens are merely receiving the benefits of their investment in the state government-that they are, in a sense, recapturing their taxes through cash or in-kind distributions from the state.

\section{A. The Model's Normative Foundations}

Allowing states to discriminate against non-residents so as to ensure that residents receive the benefit of their taxes is justified for two reasons. First, excluding non-residents from the benefits of state-created goods and services accords with basic notions of political fairness. States are, after all, political communities in which citizens decide what services they expect of the state (e.g., police, schools, medical care for the needy, etc.) and agree to pay for those services through taxes. Indeed, as Alexander Hamilton acknowledged, the federal structure created by the Constitution presumes that "the individual States should possess an independent and uncontrollable authority to raise their own revenues for the supply of their own wants." 132 On this view, it is fair for the citizens to decide to restrict the benefits of state-created resources to state residents because they are the ones who paid for such benefits.

Second, reserving the benefits of state-funded programs to in-state residents also fosters an optimal degree of public investment. Out-of-state individuals who receive the benefits of such state-created programs are, in economic and moral terms, "free riders;" they receive the benefits of programs for which they have not paid. Aside from its inherent unfairness, free riding discourages investment both by private businesses and

132 The Federalist No. 32, at 241 (Alexander Hamilton) (Benjamin Fletcher Wright ed. 1961). 
governments. ${ }^{133}$ No private business would open a restaurant if everyone could obtain a meal without paying for it. Similarly, no state woúld choose to open a public university if every student in the nation were entitled to go there for free. As one Court of Appeals accurately observed, local residents "are unlikely to pay for local government services if they must bear the cost but the entire nation may receive the benefit."134

Private businesses solve the free rider problem by charging a user fee for the good or service and correspondingly excluding those who do not pay the fee.' For a variety of reasons, however, states cannot or do not want to employ a system of user fees for all state goods and services. ${ }^{135}$ As a consequence, some governmental goods and services must be and are funded through state and local taxes, but constitutional limitations restrict the ability of states to tax non-residents. For example, states may not tax non-residents' income earned outside the state or their property held outside the state. Only those non-residents who engage in some taxable activity within the state, such as by purchasing goods within the state or staying in hotels, are subject to the state's taxation and then only to the extent of their in-state taxable activity. ${ }^{136}$ As one might expect, the actual money earned from non-residents through these taxes comprises a tiny percentage of each state's total tax receipts. ${ }^{137}$

Because of the states' inability to tax non-residents, states can only solve the free rider problem by denying out-of-state residents a ride-that is, by reserving such publicly-funded programs to state citizens on preferential terms. Such discriminatory treatment of non-residents rewards state investment in public goods and, for that reason, is legitimate. ${ }^{138}$ Liberated from the discouraging impact of out-of-state free riders, states are more

133 See Gergen, supra note 9, at 1112.

134 Swin Res. Sys., Inc. v. Lycoming County, 883 F.2d 245, 251 (3d Cir. 1989); see also Levmore, supra note 9, at 586-587; Regan, supra note 8, at 1194; Varat, supra note 9, at 522.

135 For so-called "public goods," such as police protection, the state is unable to levy a fee upon those individuals who benefit from the good or service. And, even with respect to private goods for which a fee can be charged, state residents often get upset and complain about paying user fees for government services that they believe, rightly or wrongly, they have already paid for through their taxes.

136 Varat, supra note 9 , at 527-28.

137 For example, in 2004 in California, state residents paid $\$ 36$ billion in personal income taxes to the state, while non-residents paid only $\$ 1.7$ billion-or less than $5 \%$ of the state's income tax collection. See California Statistical Abstract, Table D-10 at 84 (2006), http://www.dof.ca.gov/HTML/FS_DATA/STAT-ABS/2006_statisticalabstract. pdf.

138 Martinez v. Bynum, 461 U.S. 321, 328 (1983) (upholding state residency requirement for tuition-free public schooling because it "furthers the substantial state interest in assuring that services provided for its residents are enjoyed only by residents"); Gergen, supra note 9, at 1112. 
likely to invest in public programs at an optimal level that reflects their citizens' collective judgment as to what services they want and are willing to pay for.

To be sure, the investment capture model-or at least the underlying notion of political fairness upon which it rests-is not new. Although the Supreme Court has not rested the market participant exception on this ground, several lower courts have made fleeting references to the essential fairness of reserving state-created benefits for state residents. ${ }^{139}$ Moreover, although they draw different doctrinal conclusions from it, academic supporters of the market participant exception have justified the doctrine on this basis. Professor Varat has argued that, "[l]ike other groups free to combine their members' efforts to produce collective benefits to be shared among the group, political communities, including states, have a prima facie justification for limiting distribution of their public goods to those who combined to provide them."140 More tersely (and prosaically), Professor Coenen has declared, "the citizens of a state may reap where they have sown." 141 Even Hans Linde, a critic of the market participant doctrine, has acknowledged the propriety of allowing states to provide some preferential treatment for state citizens in distributing taxpayer-funded services on this basis. ${ }^{142}$

The principal objection to the investment capture theory concedes the essential fairness of excluding those who do not pay state taxes from state benefits but argues that there is not a sufficient linkage between state citizenship and the payment of taxes to justify treating out-of-state residents in a discriminatory fashion. This view emphasizes that some non-residents pay substantial taxes to states in which they do not reside, ${ }^{143}$ while many residents of states pay no or little taxes. In light of this, it is unfair, so the argument goes, to deny taxpaying non-residents access to benefits they have helped fund, while allowing non-taxpaying residents to receive the benefit of services to which they have not contributed.

139 Smith Setzer \& Sons, Inc. v. South Carolina Procurement Review Panel, 20 F.3d 1311, 1323 (4th Cir. 1994) (noting state's legitimate interest in channeling taxpayer money to state residents); GSW, Inc. v. Long County, 999 F.2d 1508, 1513 (11th Cir. 1993) (noting state's legitimate interest in limiting benefits of state programs to those "who fund the state treasury and whom the State was created to serve").

140 Varat, supra note 9, at 523.

141 Coenen, supra note 9 , at 423.

142 Linde, supra note 11 , at 64 (noting that states may charge non-residents higher tuition at state universities since state citizens have already partially funded their education through taxes).

143 For example, Connecticut and New Jersey residents who work in New York City are subject to New York State's income tax on their earnings. See N.Y. TAX LAW $§ 631$ (McKinney 2006). 
Of course, the investment capture defense does not deny that individual non-resident taxpayers may pay more in taxes than they receive in benefits. Rather, the investment capture defense simply rests on the fact that residents, as a class, pay substantially more in state taxes, than non-residents, as a class, and that, therefore, residency serves as a decent "proxy" for the payment of taxes and corresponding entitlement to state benefits. ${ }^{144}$ Even if that were not the case, it is far from clear that non-residents' payment of taxes would be sufficient to entitle them to state benefits. Because nonresidents, unlike residents, can easily avoid taxation by refraining from visiting or shopping in the state, their payment of such taxes could be viewed as constituting tacit consent to the fairness of the amount of taxes paid and benefits received. ${ }^{145}$

Moreover, it surely cannot be the case that states have a constitutional duty to make individualized determinations as to which individuals have paid sufficient taxes to be entitled to state benefits. Adjudicating which nonresidents deserve access to state benefits would be an enormously complex task fraught with deeply contested issues of political economy. For example, how much of a disparity between taxes paid and benefits already received is unfair? Such disparities are an inherent part of any system of taxation. Like non-residents, wealthy residents may pay much more in taxes than they receive in benefits, yet no court has ever suggested that individual taxpayers are entitled to receive public benefits corresponding to the amount of taxes paid. Such a demanding standard of tax fairness, if applied to residents, would condemn the modern, redistributive welfare state, and surely nonresidents may not demand greater tax fairness than residents receive. And, if some disparity is acceptable, how much of a disparity must exist before it is unfair? The difficulty of answering that question has dissuaded courts from engaging in individualized accounting even with respect to state citizens. ${ }^{146}$ And, not to gild the lily, but even if there were some sufficiently gross level of disparity that we could all agree is unfair, perhaps the appropriate remedy would be merely to refund the excess taxes paid rather than award the particular non-resident equal access to all state benefits.

Given these flaws in the individualized approach to assessing tax fairness, it is surely not the case that the Constitution forbids states from making class-wide determinations with regard to who has paid enough in taxes as to warrant entitlement to state benefits. ${ }^{147}$ And, the fact that residents

144 Varat, supra note 9 , at $528,529-30$.

145 See id. at 529 . Of course, the same might be said of residents, who (as Thiebout pointed out) can vote with their feet and relocate.

146 Id. at 529 \& n. 173.

147 of course, certain classifications would be forbidden by other constitutional provisions, such as the Equal Protection Clause. 
typically pay more in taxes than non-residents provides a sound basis for treating residents as possessing a special claim of entitlement to such benefits. ${ }^{148}$

\section{B. Doctrinal Framework}

The investment capture defense provides a normatively attractive foundation for the state to reserve to its citizens some state benefits, yet it still remains to flush out the doctrinal contours of the investment capture model in order to guide the judicial determination regarding which state benefits may be reserved exclusively for residents and which may not be. Obviously, the centerpiece of the model is that state citizens have a legitimate, superior claim of entitlement to those state goods and services that have been created with taxpayer funds. This formulation itself, however, suggests several limitations on the scope of the states' authority to prefer residents in the distribution of state-created goods and services.

First, a state may reserve to its citizens only those state goods and services whose creation its citizens have funded. If a particular state good or service was not created by the state or if its creation was funded in substantial part by specific fees or taxes paid by non-residents, the state citizens have no particular claim of entitlement superior to that of nonresidents. ${ }^{149}$

Second, even with respect to those goods and services funded by state taxpayers, state citizens only have a claim of entitlement to the good or service; they do not have a corresponding right to discriminate against nonresidents as such. ${ }^{150}$ Rather, the right to deny non-residents access to the good or service derives from and is contingent upon the need for such discriminatory treatment in order to vindicate the citizens' claim of entitlement. Stated differently, state citizens do not have the right to insist that non-residents be denied access to the good or service if their own access to and enjoyment of the good or service would not be hampered thereby.

This limitation on the investment capture defense's scope focuses attention on whether the good or service is exhaustible-whether a nonresident's use or consumption of the good or service thereby displaces a resident's ability to use or consume the good or service. For exhaustible goods, such as places at a public university with limited enrollment, the state

148 Varat, supra note 9, at 529-30.

149 See GSW, Inc. v. Long County, 999 F.2d 1508, 1513 (11th Cir. 1993) (noting that the market participant exception did not apply because the county had not invested any public funds in the privately-owned waste landfill).

150 Cf. Varat, supra note 9, at 531 (contending that "gratuitous" denial of access to non-residents would violate minimum rationality required by the Equal Protection Clause). 
may ban non-residents from enrolling so as to ensure maximum opportunity for residents. For inexhaustible goods or services, such as police or fire protection or access to state parks or roads, however, discriminatory exclusion of non-residents is not justified under the investment capture model. The discriminatory denial of access for non-residents is not necessary to vindicate the state's interest in satisfying the legitimate claim of entitlement to such goods or services held by residents.

Lastly, with respect to both exhaustible and inexhaustible goods and services, the state may impose a system of discriminatory user fees-that is, it may charge non-residents more for use of the good or service than it charges residents. ${ }^{151}$ Recall that residents are entitled to preferential access to goods and services because they have funded them, at least in part, through their taxes. Even if non-residents may not be or are not excluded from access to the state-provided good or service, they do not have a claim of entitlement to such goods or services free of charge. Rather, non-residents can be made to pay their way, and, to the extent that the state's taxpayers have subsidized the production of the good or service through their taxes, non-residents may be charged more than residents (who, so the theory goes, have already contributed towards the good or service) for their use of the good or service. Of course, such discriminatory user fees must bear a reasonable relationship to the actual cost of providing the good or service to the non-residents-nonresidents cannot be made to subsidize the production of the good or service for residents' benefit. ${ }^{152}$ In such a case, the excess amount paid would be akin to an impermissible tax levied exclusively upon non-residents.

In sum, a court committed to the investment capture model must focus on the relationship between the challenged state program and the state's legitimate interest in returning to its citizens the benefit of their taxes. Specifically, it would ask whether the state's citizens have funded the specific good or service and, if so, whether the discriminatory treatment accorded non-residents is necessary to vindicate the citizens' claim of entitlement to the item. This latter inquiry will itself require the court to assess whether the good or service is inexhaustible. For exhaustible goods and services, the state may legitimately exclude non-residents from any access to the good or service or charge non-residents higher fees for such good or service. For inexhaustible goods and services, discriminatory exclusion is impermissible, though discriminatory user fees are acceptable. Moreover, if the state imposes a system of discriminatory user fees (either with respect to exhaustible or inexhaustible goods and services), the court

151 Cf. Toomer v. Witsell, 334 U.S. 385, 399 (1948) (noting that a state may charge more for license fees even if it may not exclude non-residents entirely).

152 Id. at 395, 406-07 (holding license fee 100 times that for residents was unreasonable). 
must ask whether the price charged non-residents reasonably corresponds to the actual cost of providing such good or service to the non-residents.

\section{APPLYING THE INVESTMENT CAPTURE MODEL}

The investment capture defense, properly understood, requires courts to engage in a sensitive evaluation of the origins and nature of the specific good or service to determine whether state citizens have a legitimate claim of entitlement to the item that would be undermined by non-discriminatory access by residents and non-residents alike. Obviously, performing that factsensitive analysis will lead to different conclusions with respect to different types of state actions. To see how, the following sections apply this framework to some of the more common types of state programs that are typically reserved for state citizens.

\section{A. Subsidies}

Under the investment capture model, cash or in-kind subsidies to in-state businesses are generally permissible. The prototypical subsidy is a cash subsidy paid out of the state's general treasury by order of the legislature made via the ordinary appropriation process. Because such general treasury moneys are raised predominantly from state residents, they have a legitimate claim of entitlement to them. ${ }^{153}$ Moreover, because such moneys are obviously limited - there are many competing demands on the state fiscdiscriminatory treatment is permissible. Indeed, demanding states to provide subsidies on a non-discriminatory basis would undoubtedly deter states from providing any subsidies or, at the very least, reduce the amount received by in-state businesses.

Not all subsidies are permissible, however. When the subsidy is closely tied to a tax on the out-of-state competitors of the subsidized residents, the investment capture model provides no defense. In that case, the subsidy is not being funded by state residents but by out-of-state businesses. An example of such an unconstitutional subsidy is the Massachusetts tax-andsubsidy scheme invalidated in West Lynn Creamery. There, Massachusetts laid a tax on all milk sold by Massachusetts milk dealers. The proceeds of the tax were deposited in a segregated fund, which was then entirely and automatically by law distributed to Massachusetts dairy farmers. ${ }^{154}$ Because

153 Coenen, supra note 9 , at 474; Coenen, supra note 10, at 1032, 1037; Levmore, supra note 9, at 577; Varat, supra note 9, at 541. Indeed, of the commentators who endorse the market participant doctrine, only Professor Regan rejects the legitimacy of subsidies. See Regan, supra note 8, at 1196 (rejecting subsidies because their cost to taxpayers may not be sufficiently high).

154 W. Lynn Creamery, Inc. v. Healy, 512 U.S. 186, 190-91 (1994). 
the revenue generated by the tax was converted automatically into a subsidy for in-state dairy farmers, in-state farmers effectively received the tax paid on their milk plus their pro rata share of the proceeds of the tax levied on out-ofstate milk. ${ }^{155}$ For that reason, the Court was right to view the tax-and-subsidy scheme as a clever way to impose a tax that was felt only by out-of-state dairy farmers. ${ }^{156}$ In short, Massachusetts had developed a system to have out-of-state interests fund a subsidy for their in-state competitors.

Although Justice Scalia in his concurrence in West Lynn Creamery focused on the state's use of a segregated fund as the essential, unconstitutional feature of the program, ${ }^{157}$ that feature was ancillary to the real flaw in the scheme. The critical problem with the Massachusetts tax-andsubsidy program was not the use of a segregated fund but the fact that the tax proceeds were, by law, automatically transferred to the in-state dairy farmers. Even if the tax proceeds had been deposited in the general treasury, the automatic subsidy feature would still leave out-of-state dairy farmers subsidizing in-state farmers. Only if the automatic transfer were eliminated might a dairy tax and a subsequent, independent subsidy to in-state farmers pass constitutional muster.

Interestingly, the State of Maine responded to West Lynn Creamery in precisely that way. After the Court of Appeals invalidated Maine's virtually identical tax-and-subsidy scheme on the basis of West Lynn Creamery, ${ }^{158}$ the state legislature reenacted the milk tax, with the proceeds now being deposited into the general fund. ${ }^{159}$ Several months later, the legislature then enacted a series of appropriation bills that provided a subsidy out of the general fund to in-state dairy farmers. ${ }^{160}$

155 Because of this feature of the tax-and-subsidy scheme, it was not essential (as was in fact the case) that most of the milk sold in Massachusetts came from out of state. Id. at 188 (noting that $2 / 3$ of milk sold in Massachusetts was from out of state). The state of Maine had a virtually identical tax-and-subsidy system to support its dairy farmers, but most of the milk in Maine was produced in state. Nevertheless, because most of the Maine dairy tax was automatically converted into a subsidy for in-state dairy farmers, they too received both the tax paid on their milk plus their share of the taxes paid on outof-state milk. See Cumberland Farms, Inc. v. LaFaver, 33 F.3d 1, 1-2 (1st Cir. 1994) (invalidating Maine's tax-and-subsidy as indistinguishable from Massachusetts's).

156 W. Lynn Creamery, 512 U.S. at 194.

${ }^{157} \mathrm{Id}$. at $210-11$ (Scalia, J., concurring in the judgment); see also Coenen, supra note 10 , at 1040-42 (criticizing Scalia's reliance on distinction between segregated fund and general treasury).

158 Cumberland Farms, Inc. v. LaFaver, 33 F.3d 1, 1-2 (1st Cir. 1994).

159 An Act to Continue the Fee on the Handling of Milk, ch. 2, § 1-5, 1995 Me. Laws 1, 1-4 (codified at ME. REV. STAT. ANN. tit. 36, $\S \S 4771-4773$ (repealed 1998)).

${ }^{160}$ Supplemental Appropriations from General Fund, ch. 5, § A-1, 1995 Me. Laws 8, 9; Supplemental Appropriations from General Fund, ch. 368, $\$$ B-1, 1995 Me. Laws 486, 488; Appropriations, ch. 665, $\S$ KK-1, 1995 Me. Laws 1826, 1826. 
Maine may have been too clever, however. Although the Court of Appeals did not pass on the merits of the revamped Maine tax-and-subsidy-it dismissed the ensuing federal court challenge on jurisdictional grounds ${ }^{161}$-Maine's separation of the tax and subsidy into separate pieces of legislation does not per se render the scheme constitutional (as the district court held). ${ }^{162}$ If the legislature were appropriating approximately the same amount in subsidies as collected via the milk tax, the fact that there was no automatic conversion feature in the statute creating the tax would not matter. In that case, the legislature itself would simply be performing the automatic conversion itself. Whether that in fact was what was going on should have been apparent from the legislative debates and fiscal accounts. Moreover, even if there was some disparity in the amount collected and amount appropriated in a given year, a pattern of close approximation year-by-year would likewise testify to a de facto automatic conversion system. Only if the subsidy payments varied significantly from the proceeds of the tax would the Maine system differ in substance from the Massachusetts scheme invalidated in West Lynn Creamery. In that case, mixing the milk tax proceeds with all the other state revenues, together with the use of annual legislative appropriations, the amount of which bore no necessary relationship to the amount of revenue collected via the milk tax, would break the link between the milk tax and the subsidy such that the subsidy would be consistent with the investment capture model.

\section{B. Tax Exemptions and Credits}

In contrast to subsidies, tax exemptions or credits reserved for in-state goods or businesses are almost always impermissible. ${ }^{163}$ This may be shocking to some, who will rightly point out that a $\$ 5$ cash subsidy and a $\$ 5$

161 Cumberland Farms, Inc. v. Maine, 116 F.3d 943, 947 (1 st Cir. 1997).

162 Cumberland Farms, Inc. v. Mahany, 943 F. Supp. 83, 87 (D. Me. 1996); see also Coenen, supra note 10, at 1050-51 (arguing that separation of tax and subsidy distinguished Cumberland Farms from W. Lynn Creamery). Curiously, Professor Coenen argues that nevertheless, as a matter of constitutional remediation, the Maine subsidy is unconstitutional because it was enacted in response to W. Lynn Creamery. Id. at 1052 . The mere fact that a state has responded to a controlling Supreme Court decision to reform its laws, however, hardly demonstrates that the new law is unconstitutional. Perhaps Maine's subsidy is still linked as a practical matter to the milk tax, but the temporal proximity of the new legislation to the Supreme Court's decision in W. Lynn Creamery does not bear upon that issue in the least.

163 The one exception being for so-called compensatory taxes. To date, the Court has applied the compensatory tax doctrine only to sales and use taxes, but it is conceivable that a narrowly crafted tax exemption for some in-state activity could be defended on the ground that it compensates for some other tax levied exclusively on the same activity. 
tax credit are economically equivalent. ${ }^{164}$ While that is undoubtedly true, it is also undoubtedly beside the point: tax credits for in-state businesses are also economically equivalent to tariffs on out-of-state businesses, which are universally agreed to be unconstitutional. ${ }^{165}$ Economic equivalence, in other words, provides no basis for distinguishing among subsidies, tax exemptions, and tariffs. 166

Nor can the prohibition on discriminatory tax exemptions and credits be justified, as Professor Coenen and others do, on the functional ground that discriminatory subsidies are more difficult for legislatures to enact than discriminatory tax exemptions and credits. ${ }^{167}$ This view, which draws upon the public choice literature, contends that subsidies are more politically transparent because they are easily detected, of known amount, and must be reauthorized by the legislature every year, which legislators may be reluctant to do. ${ }^{168}$ Tax exemptions and credits, in contrast, can be buried amidst complex tax provisions, are of unknown cost, and, once authorized, are permanent. ${ }^{169}$ Of course, this overstates the difference between subsidies and exemptions-some subsidies can be effectively concealed from public sight and accountability, ${ }^{170}$ while some tax exemptions, particularly those listed in official tax expenditure budgets, are of known cost and readily transparent. More importantly, though, the mere fact that discriminatory subsidies may be more difficult to enact does not explain why discriminatory tax exemptions and credits, unlike their economically equivalent subsidies, should be prohibited.

164 Coenen, supra note 9, at 479.

165 W. Lynn Creamery, Inc. v. Healy, 512 U.S. 186, 193 (1994).

166 There is, admittedly, one respect in which a subsidy differs from a tax exemption. The subsidy recipient may not reinvest it in its business operations (thereby allowing it to undersell its out-of-state competitors) but rather may simply pocket the money (e.g., put it in a Swiss bank account). In such a case, there would be no impact on its competitive position vis-à-vis out-of-state businesses, and out-of-state businesses would feel no burden. Cf. W. Lynn Creamery, 512 U.S. at 215 (Rehnquist, J., dissenting) (defending Massachusetts subsidy on this basis). That discriminatory tax exemptions and credits always harm out-of-state businesses, while discriminatory subsidies only do so when the money is reinvested, seems too slender a reed to base a constitutional rule against the former, however, particularly given the legislative intent and likelihood that the subsidy will be reinvested. Coenen, supra note 10, at 1019.

167 Coenen, supra note 9, at 480-81; Coenen, supra note 10, at 983-97; see also Enrich, supra note 13, at 395, 442-43; Regan, supra note 8, at 1194 (noting that cost of subsidies may inhibit their passage).

168 Coenen, supra note 9 , at 480-81; Coenen, supra note 10 , at 985-94.

169 Coenen, supra note 10, at 985-94.

170 See Zelinsky, supra note 95, at 406-08 (noting that entitlement-based expenditure programs mirror tax exemptions in this respect). 
The critical difference between subsidies, on the one hand, and tax exemptions and tariffs, on the other hand, is neither economic nor political but structural. Unlike subsidies, which involves the payment of actual dollars previously owned by state taxpayers and contributed to the state in the form of taxes, tax exemptions or credits do not involve the transfer of dollars previously owned by taxpayers. Rather, in "granting" a tax exemption or credit, the state has merely announced that it will not take dollars from the benefited business that it would otherwise have to pay in taxes absent the exemption or credit. Money never changes hands. This distinction is crucial because what the state has "given" the benefited business is not taxpayer money but a statutory right for the business to keep its own cash. 171

This difference has constitutional salience for two reasons, one normative and one analogical. As a normative matter, the investment capture model only authorizes discrimination with regard to the distribution of state assets, such as tax dollars or state property, that the state citizens have created. It is the fact that the citizens paid taxes to the state that gives them a legitimate claim of entitlement that the state use those tax dollars, which used to be theirs, to subsidize selected state residents. In contrast, state citizens have no claim of entitlement that the state use its taxation power in a manner that favors in-state residents at the expense of their out-of-state competitors. In providing a discriminatory tax exemption or credit to certain state residents, the citizens are not giving anything of their creation or previous ownership to the favored residents. ${ }^{172}$ No cash or property is transferred from the state to the resident. Rather, the sole value received by the benefited resident-the only way in which it is better off than had the state done nothing -is the competitive advantage it receives from the imposition of taxes on its out-of-state competitors. For this reason, discriminatory uses of the state's taxation power stand on a different footing than discriminatory uses of its spending power.

Indeed, the Court expressly drew upon this distinction and gave it dispositive weight in New Energy Co. of Indiana v. Limbach. Recall that, there, the Court invalidated Ohio's motor fuel sales tax as applied to ethanol because Ohio had given a tax credit to ethanol made in Ohio but not other states. Explaining its decision, the Court announced that Ohio's actions did not fit within the market participant doctrine because they involved the "computation of taxes-a primeval governmental activity." 173 Literally

171 For this reason, I disagree with Professor Coenen that the difference between subsidies and tax exemptions is merely formal. Coenen, supra note 10 , at 980 .

172 It is on this basis that the Court has held that a tax exemption for churches does not violate the Establishment Clause, though a subsidy does. See Walz v. Tax Comm'n of N.Y., 397 U.S. 664, 675 (1970).

173 New Energy Co. of Ind. v. Limbach, 486 U.S. 269, 277 (1988). 
speaking, that did not distinguish tax exemptions from subsidies, which involve the state's spending power, which is also a "primeval governmental activity." 174 The meaning of that observation became clearer later in the opinion, however, when the Court expressly contrasted Ohio's discriminatory tax exemption with Indiana's discriminatory subsidy for its in-state ethanol industry. ${ }^{175}$ As the Court bluntly put it, "[d]irect subsidization of domestic industry does not ordinarily run afoul of [the Dormant Commerce Clause]; discriminatory taxation of out-of-state manufacturers does." 176

As an analogical matter, this difference also explains how discriminatory tax exemptions are more akin to tariffs than discriminatory subsidies. Recall that discriminatory tariffs, tax exemptions, and subsidies are all economically equivalent. What makes discriminatory tax exemptions and credits different from discriminatory subsidies is again the fact that the benefited resident does not receive actual cash from the state via its spending power but rather only the competitive economic advantage that results from the state's taxation of its out-of-state competitors. In that respect, however, discriminatory tax exemptions and credits are identical to tariffs, which likewise only benefit state residents in that indirect sense.

For this reason, the Court has been right to analogize discriminatory tax exemptions and credits to tariffs rather than to discriminatory subsidies. Thus, for example, in Bacchus Imports, Ltd. v. Dias, the Court invalidated Hawaii's discriminatory tax exemption for certain domestically-produced intoxicating beverages because the measure operated to raise the relative costs of out-of-state liquors. ${ }^{177}$ And, in Camps Newfound/Owatonna, the Court invalidated Maine's discriminatory property tax exemption for charities that served in-state residents, noting expressly that the measure was "an export tariff that targets out-of-state consumers by taxing the businesses that principally serve them."178

174 Coenen, supra note 10 , at 1013.

175 New Energy, 486 U.S. at 278.

${ }^{176}$ Id.; see also Camps Newfound/Owatonna, Inc. v. Town of Harrison, 520 U.S. 564, 590 (1997) (reaffirming distinction between discriminatory subsidies and discriminatory tax exemptions); Pelican Chapter, Associated Builders \& Contractors, Inc. v. Edwards, 128 F.3d 910, 918-19 (5th Cir. 1997) (holding that property tax exemption does not fit within market participant doctrine because taxation is sovereign, not proprietary, function); Enrich, supra note 13, at 442.

177 Bacchus Imports, Ltd. v. Dias, 468 U.S. 263, 273 (1984).

178 Camps Newfound/Owatonna, 520 U.S. at 580-81; see also W. Lynn Creamery, Inc. v. Healy, 512 U.S. 186, 194-95 (1994) (viewing tax-and-subsidy as discriminatory tax exemption, which is akin to tariff). In Camps Newfound/Owatonna, the Court also rejected the notion that discriminatory tax exemptions were equivalent to a state purchase 
Lastly, a word to those who may find the foregoing analysis too formal: The notion that discriminatory tax exemptions and credits are unfair to burdened out-of-state interests in a way that discriminatory subsidies are not may strike some as far fetched, particularly given their economic equivalence. Yet, the proof is in the pudding: while out-of-state interests regularly challenge discriminatory tax exemptions and credits, there is no similar pattern of challenges to discriminatory subsidies. ${ }^{179}$ In short, the victims of discriminatory tax exemptions and credits see a difference.

\section{State Purchases and Sales}

Virtually every state has purchasing preference rules that require governmental purchasing agents to favor in-state vendors when buying items for government use. The economic impact of these rules can be significant, particularly for vendors of goods for which the government is the largest purchaser. ${ }^{180}$

As a general rule, such preferential purchasing policies are consistent with the investment capture model. ${ }^{181}$ The reason for this is clear: in purchasing goods or services, the state is spending its own money, which is raised predominantly from state citizens. As such, state citizens have a legitimate claim of entitlement to be favored by the state when it decides to purchase items, such as pens or gasoline, for state use. ${ }^{182}$ Moreover, because state purchasing dollars are limited, such discrimination is not gratuitous.

of the exempted item, observing that such a rule would effectively license tariffs and other discriminatory taxes too. Camps Newfound/Owatonna, 520 U.S. at 594.

179 Perhaps this absence of challenges is due either to a lack of standing or the belief that any challenge would be futile. The Court's decision in Bacchus Imports alleviates any concern about the lack of standing, see Bacchus Imports, 468 U.S. at 267 (holding that change in competitive position is injury sufficient for standing), and the Court's repeated assertions that the constitutionality of direct subsidies is an open question addresses the second concern. See Camps Newfound/Owatonna, 520 U.S. at 589; W. Lynn Creamery, 512 U.S. at 199 n.15; New Energy, 486 U.S. at 278. Admittedly, cash subsidies are less common than tax exemptions, but subsidies do exist. See Coenen, supra note 10 , at 1053 .

180 See also Coenen, supra note 9, at 443-44; Linde, supra note 11, at 53-54.

181 See Smith Setzer \& Sons, Inc. v. South Carolina Procurement Review Panel, 20 F.3d 1311, 1320 (4th Cir. 1994); J.F. Shea Co., Inc. v. City of Chicago, 992 F.2d 745, 749 (7th Cir. 1993); Trojan Technologies, Inc. v. Pennsylvania, 916 F.2d 903, 911-12 (3d Cir. 1990); cf. Wyoming v. Oklahoma, 502 U.S. 437, 461 (1992) (suggesting that a state decision to purchase a certain percentage of in-state coal for a state-owned power plant would be permissible).

182 Chance Mgmt., Inc. v. South Dakota, 97 F.3d 1107, 1111,1113 (8th Cir. 1996); Am. Yearbook Co. v. Askew, 339 F. Supp. 719, 725 (M.D. Fla. 1972); Coenen, supra note 9, at 444; Varat, supra note 9, at 546; see also Big Country Foods, Inc. v. Board of 
Likewise, states may typically decide to whom they wish to sell statecreated goods and services. Because taxpayer funds are used to create the good or service, the same analysis holds: state citizens have a legitimate claim of entitlement to preferential access to such goods or services. ${ }^{183} \mathrm{On}$ this basis, the Court's decision in Reeves reached the right result, albeit not for the reasons assigned by the majority. Because South Dakotan taxpayers had paid for the state-owned cement plant, they had a superior right to its product. $^{184}$

This general rule in favor of allowing discrimination with respect to state purchasing and asset disposition policies, however, is not absolute. There are two special circumstances that warrant particular attention: (1) when the state has a monopoly or monopsony on the good or service, and (2) when the state is attempting to use its leverage to control its trading partners' conduct with respect to other private entities (the issue of so-called "downstream restraints").

\section{State Monopoly and Monopsony}

The prototypical case for applying the market participant exception involves instances in which the state is just one of many buyers or sellers of the particular good or service. In such cases, the state's discriminatory policy is typically viewed with less alarm because the excluded non-resident buyers and sellers can find other individuals with whom to deal. Thus, for example, in upholding Virginia's policy of selling only Virginia-made wines in stateowned liquor stores, the Court of Appeals emphasized that there were more than 10,000 other, private wine retailers in the state to whom customers could turn to purchase their favorite California Cabernet or French Burgundy. ${ }^{185}$

Educ., 952 F.2d 1173, 1180 (9th Cir. 1992) (upholding market participant doctrine as applied to discriminatory milk purchasing policy funded in part with federal funds).

183 Coenen, supra note 9, at 445-46; Varat, supra note 9, at 549; see also Brooks v. Vassar, 462 F.3d 341, 360 (4th Cir. 2006) (upholding Virginia policy of stocking only Virginia-made wines at state-owned liquor stores); Swin Res. Sys., Inc. v. Lycoming County, 883 F.2d 245, 249-50 (3d Cir. 1989) (upholding county policy to charge more for disposal of out-of-state waste at county-owned landfill).

184 See also Chance Mgmt. v. South Dakota, 97 F.3d 1107, 1111, 1113 (8th Cir. 1996) (upholding South Dakota's refusal to sell video gaming licenses to non-residents because state had invested taxpayer money in developing technology used in the machines).

185 Brooks, 462 F.3d at 357; see also Big Country, 952 F.2d at 1181 (upholding market participant doctrine as applied to state milk purchasing policy because state did not have monopsony on purchases of milk); Am. Yearbook Co. v. Askew, 339 F. Supp. 719, 720 (M.D. Fla. 1972) (noting that printing company excluded from state business still supplied private printing needs). 
The equities of the situation look different, however, if the state is the lone seller or purchaser of the particular good or service. In such instances, the state's status as a monopolist seller or monopsonist purchaser can leave excluded non-residents with no alternative customers, at least within that particular state. ${ }^{186}$ The critical question is whether these considerations alter the analysis and justify prohibiting states from favoring residents when they act as a monopolist or monopsonist.

In my view, the central consideration is whether the state's monopoly status is either the product of state law (a monopoly by law) or is the result of prohibitively high entry barriers (natural monopoly). The fact that private competitors cannot emerge either because of state law or the existence of a natural monopoly removes the state's otherwise proprietary actions from the scope of the investment capture defense. With regard to monopolies by law, the fact that the state has banned private competition transforms the character of the state's actions. ${ }^{187}$ The state is no longer simply returning taxpayer created goods or services to the residents who funded their creation; it is also denying non-residents access to the goods or services through its monopoly status. Such monopolistic exclusion is necessary neither to promote political fairness nor to prevent non-resident free riders.

For this reason, in my view, the Court of Appeals reached the wrong result in Chance Management, Inc. v. South Dakota. ${ }^{188}$ There, South Dakota created a state video gaming enterprise and expressly forbade private gaming companies from entering the market, thereby giving the state a legal monopoly in the provision of video gaming services. ${ }^{189}$ After investing several million taxpayer dollars in creating some of the technology to be used in the gaming consoles, ${ }^{190}$ South Dakota then adopted the policy that it would not license companies to provide video gaming services unless they were owned by residents. ${ }^{191}$ Repeatedly emphasizing that the state had invested taxpayer dollars in creating the video gaming enterprise, a divided

186 Of course, there will often be dispute as to whether the state possesses a monopoly. Compare Brooks, 462 F.3d at 357 (stating that state competed with numerous retailers in wine market) with id. at 363 (Goodwin, J., concurring and dissenting) (stating that state had monopoly on wine sales at liquor stores).

187 See Brooks, 462 F.3d at 363 (Goodwin, J., concurring and dissenting) (arguing that, because the state had a legal monopoly on liquor stores, its discriminatory policy of stocking only Virginia-made wines fell outside the market participant exception).

18897 F.3d 1107 (8th Cir. 1996).

189 Id. at 1109 (discussing S.D. CoNST. art. III, $\S 25$, which bans all lotteries except the lottery owned and operated by the state).

190 Id.

191 S.D. CoDIFIED LAws $\S 42-7 A-43$ (2004). Individual operators had to be residents, while corporate operators had to be majority owned by residents. $I d$. 
panel of the court upheld the South Dakota policy as within the market participant exception. ${ }^{192}$

The fact that South Dakota had a monopoly over video gaming services in the state-that private gaming companies could not enter the market to compete with the state-proved to be the central issue dividing the panel. For the majority, the state's monopolistic status was simply immaterial. As the majority conclusorily put it, the fact that the state "is the dominant actor in the market does not mean it is not a participant."193 For Judge Lay, who dissented, the fact that South Dakota possessed a legal monopoly rendered the state's actions more akin to regulation of the market, than mere participation in it. ${ }^{194}$ As Judge Lay correctly noted, the state was not merely deciding with whom to deal, it was also excluding non-residents from the video gaming industry in the state by prohibiting private video gaming services to open-a classic regulatory action. ${ }^{195}$

Natural monopolies pose a closer question, but the result is the same in my view. Because, by hypothesis, it possesses a natural monopoly, the state need not fear any free rider problems-the fact that private competitors cannot emerge because of the prohibitively high entry costs means that the state can charge all users of its good or service whatever price necessary to recoup its costs. For that reason, any discriminatory exclusion of nonresidents would be gratuitous and therefore outside the scope of the investment capture defense. Thus, although the state has not created the monopoly, it has availed itself of the benefits of the natural monopoly, and, in so doing, it has in a sense assumed the obligation to deal with all potential customers on a non-discriminatory basis. ${ }^{196}$

192 Chance Mgmt., 97 F.3d at 1111.

$193 \mathrm{Id}$. The majority subsequently noted that the excluded non-residents could deal with other private gaming businesses in South Dakota, such as horse and dog racing. Id. at 1114 . That observation was entirely beside the point, however. The majority itself, in another part of the opinion, had noted that the relevant market in which the state was participating was limited to video lottery services, not all forms of gambling. Id. at 1112 . Thus, the state had excluded non-residents entirely from the particular market at issue. In short, the fact that the company could enter the dog racing business no more justified its exclusion from the video lottery business than the fact that the company could still enter the food-and-beverage or hedge fund business in South Dakota.

194 Id. at 1119 (Lay, J., dissenting).

195 Id.

196 Varat, supra note 9, at 536 (noting similar requirements are imposed on private businesses by virtue of antitrust and common law). The best example would be a public utility, such as an electric company. It is inconceivable that a state could deny electrical service to vacation homes owned and used periodically by non-residents. $C f$. Coenen, supra note 9 , at 485 (discussing similar hypothetical for non-resident corporations). Even if taxpayer dollars have subsidized the construction of the utility, the state can vindicate 
Support for this view comes from Western Oil and Gas Association v. Cory. ${ }^{197}$ There, petroleum refiners brought a Dormant Commerce Clause challenge to the State of California's imposition of a new rental fee upon petroleum refiners for their pipelines that crossed the State's submerged lands. The Court of Appeals rejected the State's defense that the market participant doctrine applied because it was merely acting in a proprietary capacity as the lessor of state-owned submerged lands. ${ }^{198}$ Elaborating, the court emphasized the State's monopoly status:

The permanency of [the refiners'] facilities does not permit them to "shop around". There is no other competitor to which they can go for the rental of the required strip of California coastline. The Commission has a complete monopoly over the sites used by the oil companies. The companies have no choice but to renew their leases despite the volumetric rate, as the oil, gas and petroleum-derived products cannot be transported to plaintiffs' facilities without traversing the state-owned lands. ${ }^{199}$

In short, there was simply no other way for the oil companies to transport their product except through pipelines over the State lands. Thus, the court was right to apply the Dormant Commerce Clause to the State's attempt to capitalize on its natural monopoly. ${ }^{200}$

Absent these two types of monopolies, however, the fact that the state has a monopolisitic or monopsonistic position should not detract from its ability to choose with whom it wishes to deal. In such cases, the state's monopoly power is a mere fortuity arising from the fact that private competitors have not emerged. That they can and might still emerge is reason enough to allow the state to choose with whom it wishes to deal. ${ }^{201}$ Thus, for

its interest in returning value to its taxpayers/electric customers by charging the nonresidents more for the electricity; there is no need to exclude non-residents entirely.

197726 F.2d 1340 (9th Cir. 1984).

198 Id. at 1343.

199 Id.

200 The court invalidated the challenged rental fee as an impermissible burden on interstate commerce. Id. at 1345 . It would seem to follow a fortiori that a discriminatory policy-i.e., had California refused to rent its submerged lands except to California companies-would likewise have been invalid. $C f$. Shell Oil Co. v. City of Santa Monica, 830 F.2d 1052, 1060 (9th Cir. 1987) (declaring discriminatory access to lands over which state has monopoly would offend Dormant Commerce Clause).

${ }^{201}$ In this respect, my approach differs from that of Professors Varat and Coenen, who both urge a more flexible, holistic, all-factors-considered approach. Varat, supra note 9, at 540; Coenen, supra note 9, at 484-85. Professor Varat, in particular, would focus on the importance of the good or service and its availability in other states, including the non-resident's home state. Varat, supra note 9, at 533, 537, 539 \& n.191. Such an approach would undoubtedly be appropriate for Congress to use in deciding 
example, the Court was right in Reeves to hold that South Dakota could reserve its cement from its state-owned plant exclusively for state residents, despite the fact that the plant was the only one in the state. As the Court observed, there was no legal or practical barrier to the establishment of additional cement plants in the state. ${ }^{202}$ Consequently, the state's monopoly position was purely the result of private choices made by other cement manufacturers not to enter the South Dakota market. ${ }^{203}$ That they could do so at any time served as a powerful incentive for the state to limit its discriminatory actions and thereby minimized the concern that the state's discriminatory policy would last longer than necessary. ${ }^{204}$

\section{Downstream Restraints}

Once again, the prototypical case for application of the investment capture defense is when the state is agreeing to trade only with in-state vendors or buyers. ${ }^{205}$ In such cases, the state's discriminatory action is clearly tied to ensuring that the state's tax dollars remain in the state, at least initially.

The situation changes, however, if the state is focusing not on who it deals with but rather who its trading partners in turn do business with. This is the problem of "downstream restraints"-the state is attempting to use its purchasing power to control the behavior of its trading partners by conditioning its willingness to trade with them on their agreement to favor residents. ${ }^{206}$

when state discriminatory purchasing and sales policies should be outlawed, but, in deciding what the Constitution prohibits, such ad hoc inquiries threaten to destabilize the principled adjudication of cases and leave both states and private parties uncertain as to their legal rights and responsibilities.

202 Reeves, Inc. v. Stake, 447 U.S. 429, 444 (1980) ("Nor has it restricted the ability of private firms or sister States to set up plants within its borders.").

203 Indeed, South Dakota's monopoly status arose only by virtue of the fact that the private cement plant closed as part of an effort to drive up regional prices in cement. See id. at 431 n.1.

204 In fact, South Dakota eliminated the discriminatory policy once economic conditions changed. Id. at 434 n.5. That should hardly be surprising; it had every reason not to discriminate when supply outstripped domestic demand so as to increase its own revenues and to prevent the development of other cement plants, which might compete with the state with respect to both in-state and out-of-state buyers.

205 See, e.g., Reeves, 447 U.S. at 442; Am. Yearbook Co. v. Askew, 339 F. Supp. 719, 725 (M.D. Fla. 1972) (upholding state statute requiring all printing services purchased by state be done in state).

206 Downstream restraints can also arise in the context of tax exemptions. See, e.g., Pelican Chapter, Associated Builders \& Contractors, Inc. v. Edwards, 128 F.3d 910, 919 
The constitutionality of downstream restraints is a complex question, and the categorical answers provided by the Court and some commentators elide important distinctions. ${ }^{207}$ In my view, the key factor to consider is whether the downstream restraint is linked to the state's legitimate interest in channeling state funds and resources to state residents. If so, the restraint falls within the investment capture defense; if not, the restraint falls outside that defense. Applying this criteria, some, but not all, downstream restraints are constitutional. Moreover, the analysis, though conceptually the same, differs somewhat in detail depending on whether the state is tying the downstream restraint to a purchase of some good or service from a private vendor versus a sale of some state-created good or service to a private purchaser.

\section{a. State as Purchaser}

An example of a perfectly permissible downstream restraint is that at issue in White. Recall that, there, the City of Boston required all contractors on city-funded public works to ensure that $50 \%$ of their workers were residents of Boston. ${ }^{208} \mathrm{By}$ its terms, the city order applied to all projects in which any city funds were expended, but the Court expressly limited its consideration of the issue to those public works that were funded entirely by the city. ${ }^{209}$ It was on this basis that the Court was able to conclude that the benefited residents were, "in a substantial if informal sense, working for the city." 210 Indeed, the Court again emphasized that feature in upholding the order, declaring that "[i]nsofar as the city expended only its own funds in entering into construction contracts for public projects, it was a market participant and entitled to be treated as such."211

Although the Court did not justify its decision upholding Boston's discriminatory hiring policy in these terms, it is easy to see how its policy fits

(5th Cir. 1997) (invalidating a property tax exemption that was conditioned on taxpayer's agreement to ensure that in-state products and labor were used).

207 See Wunnicke, 467 U.S. at 97 (holding that a state may not impose conditions on activities outside markets in which it participates); Coenen, supra note 9, at 473 (arguing for a general rule prohibiting downstream restraints); Varat, supra note 9, at 564 (arguing for a general rule prohibiting downstream restraints in context of disposition of state resources).

208 White, 460 U.S. at 205-06 \& n.1.

209 Id. at 209. The Court also considered the propriety of the order as applied to public works funded with federal tax dollars, and, with respect to these construction projects, the Court held that Congress had affirmatively authorized such discriminatory policies with respect to federally-funded public works. Id. at 213.

$210 \mathrm{Id}$. at $211 \mathrm{n} .7$ (internal quotation marks omitted).

211 Id. at 214-15. 
within the investment capture defense. Because only city funds were at stake, it was legitimate for the city to demand that the contractors prefer city residents in working on the city-funded projects. The purpose of the restraint was to ensure that tax dollars (and only those dollars) remained in the local economy. ${ }^{212}$

As the Supreme Court recognized in White, however, the validity of downstream restraints becomes more clouded if the government is attempting to control its trading partner's behavior with respect to activities that are not funded exclusively by the government. In such cases, the constitutionality of the downstream restraint properly turns on a fact-intensive investigation that compares the extent of the public funding and the cost of the demanded preference. Let's change the facts from White so that Boston is providing only a portion of the costs of construction. If Boston contributed $\$ 50$ million to a $\$ 100$ million construction project, but employing the designated number of Boston residents would cost $\$ 40$ million, the restraint would still be constitutional as applied to this hypothetical project. As in White itself, it is still fair to say that the benefited residents work for the city; in essence, the city contribution is akin to a subsidy to the contractor in return for the contractor's promise to use the funds to hire city residents. In such case, the restraint is ensuring that city tax dollars (and only those dollars) remain in the city to the best extent possible.

Now suppose that Boston contributed only $\$ 25$ million to the construction project, but employing the mandated number of Boston residents still cost $\$ 40$ million. In this case, the condition would be unconstitutional. The city-provided funds do not cover the expense of employing the city residents, so it is no longer fair to view the benefited

212 See also Am. Yearbook Co. v. Askew, 339 F. Supp. 719, 725 (M.D. Fla. 1972) (upholding state statute requiring all state printing to be done in state); Allen v. Labsap, 87 S.W. 926, 928 (Mo. 1905) (upholding an ordinance requiring all stone to be used in public works to be finished in state). But see Treat v. Coler, 59 N.E. 776, 778 (N.Y. 1901) (invaliding similar New York statute). In Treat, Chief Justice Parker dissented precisely on the ground, not discussed by the majority, that the state was not subject to the Dormant Commerce Clause when it was deciding how taxpayer funds were spent on public works. Id. at 779 (Parker, C.J., dissenting). Moreover, not to gild the lily, the U.S. Supreme Court expressly discredited Treat. See Reeves, 447 U.S. at 437 n.9.

Professor Coenen distinguishes the stone finisher cases from White on the ground that, because stone finishers "often are both physically and temporally removed from the construction project," they do not work for the city like the benefited construction workers in White. See Coenen, supra note 9, at 471 . Not only does that distinction embroil courts in the difficult task of deciding what type of workers can be said to work for the city (day laborers, yes; stone finishers, no), it is entirely immaterial to the central question whether the restraint is related and limited to the state's or city's investment. If, for example, the government has entirely funded the public works, it may insist that all work on the project, no matter of what nature, be done in state. 
workers as employed by the city. Rather, the city is requiring the contractors to use funds obtained elsewhere (not from the city itself) to employ city residents. And, because the city has no legitimate interest in demanding that the contractors spend their own funds to favor city residents, the restraint in this case would be unconstitutional. ${ }^{213}$

Perhaps the clearest example of an unconstitutional downstream restraint is where the restraint is entirely unrelated to any state expenditure or investment of state resource. In such case, the state is not recouping the benefits of any state funds but is trying to mask its regulatory actions in contractual garb. Thus, for example, the Court of Appeals was right to condemn the discriminatory waste disposal policy at issue in GSW, Inc. v. Long County. ${ }^{214}$ There, the county government in Alabama entered into a contract with a private, Georgia-based company to build a landfill within the county. ${ }^{215}$ After the contract was signed, the county government demanded that the company not accept waste from beyond 150 miles, and, when the company refused to accept that limitation, the county rescinded its contract. $^{216}$

Invalidating the county's actions, the Court of Appeals correctly noted that no tax dollars were at stake-that the county was not a partner of the private company in developing the landfill. 217 The county's "contribution" to the landfill was limited to the issuance of a license to the company and some

213 See also Hicklin v. Orbeck, 437 U.S. 518, 530 (1978) (invalidating state law that required lessees of state property to hire residents because the statute "extends to employers who have no connection whatsoever with the State's oil and gas, perform no work on state land, have no contractual relationship with the State, and receive no payment from the State"); Nat'l Foreign Trade Council v. Natsios, 181 F.3d 38, 63 (1st Cir. 1999) (rejecting market participant doctrine as applied to state law requiring companies doing business with the state to divest from Burma because the law "appl[ies] to activities not even remotely connected to such companies' interactions with Massachusetts"). For the same reason, the New Jersey Supreme Court was right (although not for the reason it relied upon) that the market participant doctrine did not shield a New Jersey statute that required all suppliers of milk to state agencies to certify that they had purchased as much New Jersey milk in both the preceding year and in the contract year as would be sold to the state. See Garden State Dairies, Inc. v. Sills, 217 A.2d 126, 130 (N.J. 1966). As Professor Coenen rightly points out, the statute required the milk vendors to purchase from in-state sources double the amount of milk actually sold to the state, thereby effectively requiring the vendors to subsidize the New Jersey dairy industry by purchasing New Jersey milk for sale to other private buyers. Coenen, supra note 9 , at 472 .

214999 F.2d 1508, 1517-18 (11 th Cir. 1993).

215 See GSW, Inc. v. Long County, No. CIV. A. CV292-54, 1992 WL 535401, at *1-2 (S.D. Ga. June 29, 1992).

216 GSW, Inc., 999 F.2d at 1510.

217 Id. at 1513. The court noted that, had the county invested its own funds in developing the landfill, it could conceivably claim to be a market participant. Id. \& n.5. 
assistance with state regulators. In essence, the county was conditioning the issuance of regulatory approval for the landfill upon its agreement not to accept certain waste. As such, the county's insistence that' the private company refuse to accept waste from other generators outside the 150-mile limit was, as the court correctly held, an attempt "to gain benefits for its constituents without providing any funding for the program, rendering the policy more regulatory than participatory." 218

\section{b. State as Seller}

Lastly, there is the issue of the validity of downstream restraints in the context of state dispositions of state-owned resources. The Court addressed this issue in Wunnicke. Recall that, there, the Court invalidated Alaska's requirement that purchasers of state-owned timber have the logs processed in-state by private timber processing companies. ${ }^{219}$ As the Court ruled, Alaska could not claim the protection of the market participant doctrine because Alaska was not a participant in the timber processing market-it was instead attempting to leverage its control over the sale of state-owned timber to affect the behavior of purchasers in the downstream, timber-processing market.

From the perspective of the investment capture defense, the Court's mind-your-own-market rule makes no sense. A state has a legitimate interest in ensuring that taxpayer investments accrue to the benefit of state residents. Thus, to the extent that Alaska had invested in its timber resources-such as by farming the timber-it had a corresponding right to see that its investment inured to the benefit of state residents, even if those residents were not the first purchasers of the timber. The choice as to which residents should benefit from the state's investment is for the state to make. ${ }^{220}$

Instead of drawing the categorical (yet still elusive) rule against downstream restraints in other markets, the Court should have focused on whether the restraint was linked to ensuring that taxpayer funds be used for the benefit of state taxpayers. Although the context differs, the analysis of downstream restraints attached to state dispositions of state assets (Wunnicke) does not differ conceptually from that of restraints attached to state purchases of private goods and services (White). With state purchases, the inquiry is whether the state's cash payment is sufficiently large to cover

218 Id.

219 South-Central Timber Dev., Inc. v. Wunnicke, 467 U.S. 82, 97-99 (1984).

220 Alaska could have agreed to sell its timber only to Alaska timber purchasers, which would clearly be constitutional. See Reeves, Inc. v. Stake, 447 U.S. 429, 446-47 (1980). That it chose to use its "investment" for the benefit of timber processors rather than timber purchasers should present no issue of federal constitutional magnitude. 
the contractor's cost of dealing with the benefited state residents; with state sales and other dispositions of state assets, the inquiry is whether the terms of the disposition are such that it can be viewed as an in-kind subsidy to the purchaser to deal with state residents. Specifically, the court must assess whether the state has offered an in-kind subsidy to the purchaser, such as by disposing of the state asset at less than market cost, and whether the extent of the subsidy is sufficient to cover the purchaser's cost of dealing with the benefited state residents. If the state has disposed of the state asset at the prevailing market price, there is no subsidy and, therefore, any downstream restraint is unconstitutional. ${ }^{221}$ Where the state has disposed of the state asset at less than market price, however, there is at least the possibility that the downstream restraint is simply a mechanism to ensure that the purchaser in effect transfers the subsidy to the designated, favored resident.

Where the state has disposed of a state asset at less than market price, the court must determine whether the difference in price is sufficient to cover the purchaser's cost of doing business with the specified state residents. This was the situation confronting the Court in Wunnicke-Alaska had discounted the price of the timber below the prevailing market price ${ }^{222}$ - but, unfortunately, the Court made no effort to determine whether the difference in pricing covered the cost of having the logs processed in Alaska. ${ }^{223}$ Because of that, we cannot know for certain whether the downstream restraint was simply an effort to ensure that purchasers of the timber used their in-kind subsidy for the benefit of state residents or instead was an attempt to leverage the state's control over its timber to induce private purchasers to use their own funds to subsidize the state timber processing industry. If, for example, the timber discount was $\$ 100$ per log and the cost of processing each log was $\$ 250$, the downstream restraint would be unconstitutional since the in-kind subsidy to the purchasers (the state's subsidy) would not cover the cost of the processing (the designated in-state beneficiary of the state's investment). ${ }^{224}$

221 Cf. Hicklin v. Orbeck, 437 U.S. 518, 531 (1978) (invalidating downstream restraint attached to a lease of state property because the measure was "an attempt to force virtually all businesses that benefit in some way from the economic ripple effect of Alaska's decision to develop its oil and gas resources to bias their employment practices in favor of the State's residents").

222 Wunnicke, 467 U.S. at 85.

223 Then-Justice Rehnquist viewed the timber sale as an in-kind subsidy. See id. at 103 (Rehnquist, J., dissenting). Because he made no comparison of the value of the subsidy and the cost of timber processing, however, it is unclear whether his approach is consistent with the investment capture model.

224 For this same reason, the Court of Appeals in Pelican Chapter v. Edwards, 128 F.3d 910, 919 (5th Cir. 1997), was right to invalidate Louisiana property tax exemption that was conditioned on the recipient using only Louisiana goods and workers in developing the property. Although the court decided the case on the ground that 
If, on the other hand, the discount was $\$ 300$ per $\log$, the downstream restraint would be perfectly acceptable; in that case, the restraint would simply ensure that the non-resident timber purchaser transferred the subsidy to the resident timber processor.

In short, the state's power to decide with whom it wishes to deal does not encompass the lesser power to use its market leverage to require the private parties with whom it does business in turn to agree to deal with state residents. At the same time, the state does have a legitimate interest in ensuring that state tax dollars be used for the benefit of state residents. As a consequence, those downstream restraints that serve merely to channel state subsidies to state residents via intermediate parties are permissible; those restraints that go beyond that and attempt to leverage state market power to require private intermediaries to subsidize state residents are not permissible.

\section{Natural Resources}

Natural resources present a variant of the previous issue. States often sell natural resources, and, as such, their distribution of such natural resources would seem to fall within the rule just discussed for the sale of state-owned goods and services. The distinguishing feature of natural resources, however, is the fact that they, unlike other state goods or services, are typically not the creation of the state or its taxpayers. Rather, the state is often just the fortuitous beneficiary of its geographic location. ${ }^{225}$

The notion that there is some constitutional significance to this difference first arose in Reeves. There, in upholding South Dakota's discriminatory cement sales policy, the Court expressly contrasted cement with natural resources, such as coal, timber, wild game, or minerals. ${ }^{226}$ Cement, the Court noted, "is the end product of a complex process whereby a costly physical plant and human labor act on raw materials."227 Natural resources, in contrast, are merely items that "by happenstance" are found in the state. ${ }^{228}$ To be sure, the Court in Reeves did not expressly endorse a natural resources exception to the market participant doctrine, nor did it provide a theoretical justification for treating natural resources differently. Nevertheless, Reeves

discriminatory tax exemptions can never fall within the market participant doctrine, $i d$. at 918-19, the downstream restraint feature would also be unconstitutional because, even if the tax exemption was equivalent to a subsidy, the value of the tax exemption could not conceivably cover the full cost of purchasing only Louisiana goods and employing Louisiana workers.

225 See Swin Res. Sys., Inc. v. Lycoming County, 883 F.2d 245, 251 (3d Cir. 1989).

226 Reeves, Inc. v. Stake, 447 U.S. 429, 443 (1980).

227 Id. at 444 .

228 Id. 
opened the door to consideration of whether non-residents are entitled to equal access to natural resources.

As one might suspect, the investment capture defense provides a sound theoretical foundation for a limited natural resources exception. State citizens have no legitimate claim of entitlement to natural resources whose creation they have not funded. ${ }^{229}$ With respect to natural resources that merely happen to be found in a particular state through no effort of the state itself, such as minerals and petroleum, non-residents stand in an equal position as residents. At the same time, however, state citizens do have a legitimate claim of entitlement to those natural resources that they have expended funds to create or augment, such as agricultural products grown on state-owned farms. ${ }^{230}$ Again, courts must engage in a fact-sensitive inquiry into the state's relationship to the natural resource to determine whether the resource's location in the state is merely a windfall or is the product of state investments.

Petroleum and mineral deposits provide perhaps the clearest example of a natural resource that is a windfall to the state and that therefore must be distributed on a non-discriminatory basis. ${ }^{231}$ The location of oil, gas, and mineral reserves within particular states owes nothing to the efforts of or investment by state taxpayers. As such, courts have been right to resist state efforts to restrict the benefit of such deposits to state residents. Thus, for example, in Hicklin v. Orbeck, ${ }^{232}$ the Court invalidated Alaska's requirement that lessees of state oil and gas reserves employ only residents. Rejecting Alaska's claim that its ownership of the oil and gas deposits insulated its statute from review, the Court bluntly declared that "the Commerce Clause circumscribes a State's ability to prefer its own citizens in the utilization of natural resources found within its borders, but destined for interstate commerce."233

Game and wildlife provide a more difficult situation. The Court has long since jettisoned the fiction that the state owns all wild animals in its territory and may therefore reserve them on preferential terms to state residents. In Foster-Fountain Packing Co. v. Haydel, ${ }^{234}$ for example, the Court struck

229 See Swin Res., 883 F.2d at 254 (noting that there is "some place" for a natural resource exception to market participant doctrine); cf. Coenen, supra note 9 , at 455 (arguing that sow-and-reap rationale "packs limited force" in context of natural resources).

230 Varat, supra note 9 , at 558.

231 Id. at 557; Coenen, supra note 9, at 460.

232437 U.S. 518,534 (1978).

233 Id. at 533; see also West v. Kan. Nat. Gas Co., 221 U.S. 229, 262 (1911) (invalidating state law that limited export of privately-owned natural gas to other states); Pennsylvania v. West Virginia, 262 U.S. 553, 600 (1923) (same).

234278 U.S. 1, 13-14 (1928). 
down a Louisiana statute that required shrimp to be processed in Louisiana before being exported to other states. Although the statute declared that shrimp found in Louisiana waters were the property of the state, the Court ruled that the state's ownership of the shrimp was not sufficient to justify the state's discriminatory policy. ${ }^{235}$ Likewise, in Hughes $v$. Oklahoma, ${ }^{236}$ the Court invalidated an export embargo on minnows, despite the state's claim that it owned the minnows in trust for its citizens. ${ }^{237}$ Because neither state had invested state funds in expanding these resources, the Court was right to view the state efforts as an attempt to reap an unearned windfall.

Matters become more complicated, however, when the state does undertake efforts to augment the game supply within its borders. The key in this situation is whether the state has actively augmented the wildlife stocks or whether it has merely attempted to conserve existing stocks by regulating the number of game that may be captured or taken. In the former situation, the investment capture defense provides justification for state favoritism of state residents because the state's affirmative and costly efforts to increase the game supply, such as by operating fish hatcheries and restocking lakes and rivers, provides state citizens with a legitimate claim of entitlement to the augmented game supply. In the latter situation, however, the state has not created the wildlife stocks but has merely tried to arrest the decline of the species. Although conservation efforts are often costly, they do not provide state citizens with a legitimate claim of entitlement to the wildlife any more than similar efforts would with respect to oil or gas reserves. ${ }^{238}$ The state citizenry's collective determination to restrict the taking of game does not ipso facto give them a claim upon the untaken game.

For this reason, the Court of Appeals, in Conservation Force, Inc. $v$. Manning, ${ }^{239}$ was right to invalidate an Arizona regulation that provided that no more than $10 \%$ of the hunting licenses for elk and certain deer could go to

$235 \mathrm{Id}$. at 13; see also Toomer v. Witsell, 334 U.S. 385, 399-402 (1948) (invalidating discriminatory shrimp licensing fee and rejecting claim that state's ownership of shrimp insulated fee from challenge under Article IV's Privilege and Immunities Clause).

236441 U.S. 322 (1979).

237 Indeed, the Court expressly overnuled the contrary holding of Geer $v$. Connecticut, 161 U.S. 519 (1896), that the state could restrict the taking of wild game to state residents because it owned them in trust for its citizens. See Hughes, 441 U.S. at 335 .

${ }^{238}$ Cf. Gergen, supra note 9, at 1113 (arguing that sharing resources with nonresidents does not increase cost of conservation and thus does not discourage it). But see LAURENCE TRIBE, AMERICAN CONSTITUTIONAL LAW §6-10, at 1086 n.14 (3d ed. 2000) (arguing that conservation efforts do give citizens superior claim to wildlife over nonresidents); Levmore, supra note 9, at 616 (same).

239301 F.3d 985 (9th Cir. 2002). 
non-residents. ${ }^{240}$ As the Court noted, the stock of elk and deer was the product of. state conservation efforts, not state breeding farms. ${ }^{241}$ Rejecting the notion. that state conservation efforts give state citizens a claim of entitlement to the wildlife, the court declared that "[w]here the resource in question is produced by conservation, rather than being the end product of a complex process by the state whereby a costly physical plant and human labor act on raw materials, scarcity of the resources does not itself justify discrimination against out-of-state residents." 242 Consequently, the state had to demonstrate that its discrimination was justified under the strict scrutiny applicable to regulatory measures. ${ }^{243}$

Timber provides perhaps the most difficult case for application of a natural resources exception. Large timber stands are typically the natural product of fortuitous geographic location and ample water sources. Where states merely seek to reap what nature has given them, they have no legitimate interest in excluding non-residents. ${ }^{244}$ Yet some states expend

${ }^{240} I d$. at 989 (referring to ARIZ. ADMIN. CODE § 12-4-114 (1991)).

241 Conservation Force, 301 F.3d at 989.

$242 \mathrm{Id}$. at 996 (internal quotation marks and brackets omitted). Curiously, the court subsequently suggested that some "limited consideration of residency" might be appropriate if non-residents, because of their number, were effectively excluding residents from receiving hunting licenses. Id. at 999 . The court did not explain the basis for this reservation. Perhaps the court feared that if residents do not receive some minimum level of wildlife access, they will not undertake any conservation measures. That concern, however, could be fully addressed by charging non-residents a sufficiently high license fee to cover the cost of conservation measures; limiting non-resident access is therefore more discriminatory than necessary. See Varat, supra note 9, at 560 (noting availability of less discriminatory means to promote conservation efforts).

243 Conservation Force, 301 F.3d at 995 . Subsequently, Congress overruled the Ninth Circuit and authorized states to discriminate against non-residents with respect to fish and wildlife. See Emergency Supplemental Appropriations Act for Defense, the Global War on Terror, and Tsunami Relief, Pub. L. No. 109-13, § 6063 (2005); see also Schutz v. Thorne, 415 F.3d 1128, 1138 (10th Cir. 2005) (upholding Wyoming statute that imposed quotas and higher fees for non-resident hunting licenses because of passage of federal law). For a general discussion of Congress's power to overrule the Dormant Commerce Clause and restore state authority to act in ways inconsistent with that doctrine, see Norman R. Williams, Why Congress May Not "Overrule" the Dormant Commerce Clause, 53 UCLA L. REV. 153 (2005).

${ }^{244}$ For this reason, the Court's decision in Wunnicke was correctly decided without regard to the nature of the downstream condition. The Court expressly distinguished Reeves on the ground that timber was a natural resource and was not like a state-created good. Wunnicke, 467 U.S. at 96 . That statement could only be true if Alaska was simply harvesting naturally grown timber rather than replanted trees. And, if Alaska could not reserve its timber exclusively for non-residents (because state residents have no superior claim of access to such natural resources), it follows a fortiori that the state could not demand non-resident purchasers of its timber to favor resident timber processors. Varat, supra note 9 , at 561 . 
considerable resources husbanding and augmenting their forests, such as by replanting trees after harvesting. In these states, the publicly-owned forests more closely resemble a tree farm, to which state citizens have a legitimate claim of entitlement superior to that of non-residents. As always, courts confronting state regulations governing access to state timber resources should proceed cautiously and eschew drawing categorical conclusions applicable to all states-what may hold true for Oregon may not hold true for Alaska.

Lastly, even as to those natural resources to which the state must provide non-discriminatory access, it should be noted that the state may still nonetheless be able to charge non-residents more for such resources. Many states do invest in their natural resources by making their harvesting and use possible. Since non-residents do not pay for such state-created services, the investment capture defense suggests that it is acceptable for states to charge non-residents more than residents to recoup such taxpayer-funded costs. 245 As noted above, however, courts must be duly cautious and ensure that the difference in pricing reasonably reflects the actual cost of providing nonresidents access to the natural resource.

\section{E. Inexhaustible Goods and Services: Roads, Courts, Etc.}

Lastly, there is a final sub-category of state-created goods and services that cuts across the foregoing types of state favoritism. Despite their creation by the state, some state goods and services may not be reserved on a preferential basis for state citizens. Roads are a prime example. Were a state to prohibit non-residents from using its roads and highways, there would be little doubt that the Court would invalidate the measure. ${ }^{246}$ Indeed, in South

245 Professor Varat disagrees, noting that the presence of such natural resources is a blessing for the state, providing it with a larger tax base and greater economic opportunities. Varat, supra note 9 , at 556. In his view, the natural resource is compensation enough for the state. While there is some force to this observation-the free rider problem, for example, is not likely to deter states from investing in mechanisms to exploit their natural resources given the large windfall that accrues to states from the sale of such resources-the notion that non-residents can be made to pay their own way as a matter of basic fairness provides a sufficient justification for such discriminatory pricing.

246 See, e.g., Am. Trucking Ass'n v. Whitman, 437 F.3d 313 (3d Cir. 2006) (invalidating New Jersey ban on interstate but not intrastate trucks using certain New Jersey highways); Doran v. Mass. Turnpike Auth., 348 F.3d 315, 321 (1st Cir. 2003) (noting that, after MTA proposed to provide toll discount only to state residents, concerns about constitutionality of measure prompted MTA to offer discounts to any Fast Lane users regardless of residency). But cf. Endsley v. City of Chicago, 230 F.3d 276, 284-85 (7th Cir. 2000) (rejecting Dormant Commerce Clause challenge to city's nondiscriminatory operation of a toll road because the city is a market participant). 
Carolina State Highway Department v. Barnwell Brothers, ${ }^{247}$ the Court rejected the notion that state ownership of state highways immunized road regulations from Dormant Commerce Clause challenge. ${ }^{248}$ Although the Court upheld the South Carolina regulation, it emphasized that the regulation was non-discriminatory, thereby suggesting that a different result would have obtained had South Carolina attempted to reserve its roads only for in-state trucks. Moreover, since Barnwell, the Court has invalidated several facially non-discriminatory statutes on Dormant Commerce Clause grounds, further confirming that state ownership of the roads does not remove them from the scope of the Dormant Commerce Clause. 249

Likewise, the same holds true for state-owned airports. In EvansvilleVanderburgh Airport Authority District v. Delta Airlines, ${ }^{250}$ the Court upheld a non-discriminatory $\$ 1$ fee levied on all departing airplane passengers. Like in Barnwell, the Court emphasized the non-discriminatory nature of the fee, suggesting that the outcome would have been different had the states levied the fee only on non-residents or interstate flights. ${ }^{251}$

Lower courts and commentators have typically reconciled these decisions on the ground that roads and other forms of transportation infrastructure are channels of interstate commerce deserving of special constitutional protection. ${ }^{252}$ As one Court of Appeals put it, ensuring nondiscriminatory access to state roads is "essential to an outsider's ability to do business in the state." 253 While that is no doubt true in a practical sense, determining what state-provided items are "essential" to private commerce is no easy task. Roads may be essential to the economy, but what about universities or landfills?254 There is no immediately apparent and principled basis to distinguish among those items, at least in terms of their importance to the economy.

As a consequence, any inquiry into whether a particular state-provided good or service is "essential" to interstate commerce runs the risk that every such good or service, even those that are relatively insignificant, will be

247303 U.S. 177 (1938).

248 Id. at 189; see also Linde, supra note 11, at 56, 61 (contending that public ownership is not sufficient justification for discrimination and approving Barnwell).

249 Am. Trucking Ass'n v. Scheiner, 483 U.S. 266 (1987); Raymond Motor Transp. v. Rice, 434 U.S. 429 (1978); Bibb v. Navajo Freight Lines, 359 U.S. 520 (1959).

250405 U.S. 707 (1972).

251 Id. at 717.

252 Swin Res. Sys., Inc. v. Lycoming County, 883 F.2d 245, 254 (3d Cir. 1989); Dan T. Coenen, State User Fees and the Dormant Commerce Clause, 50 VAND. L. REV. 795, 816, 822 (1997); Gergen, supra note 9, at 1132-33.

253 Swin Res., 883 F.2d at 254 (alteration omitted).

${ }^{254} \mathrm{Cf}$. Buchwald v. Univ. of N.M. Sch. of Med., 159 F.3d 487, $496 \mathrm{n} .9$ (10th Cir. 1998). 
deemed to be vital to private commerce. Indeed, this is what happened in Smith v. Department of Agriculture. ${ }^{255}$ There, the State of Georgia gave preferential access to resident farmers in leasing stall space at a state-owned farmers' market. The state owned and operated the market, and state taxpayers subsidized its operations because the fees charged farmers for use of the stalls did not cover the market's expenses. ${ }^{256}$ Indeed, as one of the judges noted, but for Georgia's taxpayers, the market would not exist. ${ }^{257}$ As a consequence, this was a classic case for application of the market participant doctrine. The state was not regulating the purchase or sale of agricultural produce in the state or even the allocation of stall spaces at farmers' markets generally; rather, it was simply allocating stall space at a market owned and operated by the state itself. 258

The Court of Appeals, however, held that the state's actions were that of a market regulator, not market participant. The court reasoned that because the state was not buying or selling the produce but "simply" providing a suitable marketplace for the purchase and sale of such produce by private individuals, the state was acting as a market regulator. ${ }^{259}$ Concurring, Judge Gee elaborated that the market participant exception did not apply because the state "has focused and localized an existing market by constructing the physical selling facility in which it is carried on." 260 The implication was that the marketplace was essential to the interstate commerce in farm produce in the area and that, therefore, the state's favoritism for resident farmers in allocating stall space was illegitimate.

Smith only involved stall space at a local farmers' market, but its sweeping rationale - that the state acts as a market regulator whenever it allocates state-created assets in a way that distorts or inhibits other private market exchanges-would encompass numerous other, more important forms of state market actions, such as selective admissions at public universities and discriminatory solid waste disposal policies at municipallyowned landfills. Indeed, the court's approach in Smith could potentially eviscerate the market participant doctrine itself.

In my view, the better way to understand and reconcile decisions such as Barnwell and Evansville-Vanderburgh is to acknowledge that roads, airports, parks, judicial systems, and the like are, in a sense, inexhaustible goods. ${ }^{261}$

255630 F.2d 1081 (5th Cir. 1980).

256 Id. at 1082 n.l.

257 Id. at 1086 (Gee, J., specially concurring).

258 Id. at 1087 (Randall, J., dissenting); see also id. at 1088.

259 Id. at 1083.

${ }^{260}$ Id. at 1086 (Gee, J., specially concurring).

261 To be sure, as Professor Varat correctly points out, these items are not literally inexhaustible. Varat, supra note 9 , at 532 . Non-residents' vehicles may potentially 
Allowing non-residents to use such goods does not diminish their availability for citizens, Non-resident use of roadways or state parks, for example, does not preclude residents from driving their vehicles on the state highways or availing themselves of the benefits of state parks. For the state, then, to exclude non-residents from state highways or parks is "gratuitous." 262 For that reason, the investment capture defense provides no refuge for state efforts to reserve such state-created goods or services exclusively for their own residents.

To be sure, it is theoretically possible that, at some point, the use of a particular good or service by residents and non-residents alike might become so great that the additional use by non-residents could be said to effectively preclude state citizens from availing themselves of the particular good or service. For example, traffic congestion could become so bad that, even if most vehicles were owned by residents, the marginal increase in congestion caused by non-residents could result in grid-lock and thereby deny residents use of roads they have created. At this point, the otherwise inexhaustible good or service could be said to be exhausted. Would it then be permissible for the state to exclude non-residents so as to return the good or service to working order?

My answer is something of a punt. One would hope that the state would use non-discriminatory alternatives to reduce congestion, such as New York City's proposal to impose a congestion-based user fee for driving into the business district in Manhattan, but the Dormant Commerce Clause would not require that it do so. At the same time, however, the Dormant Commerce Clause is concerned only with interstate equality with respect to commerce. Discriminatory restraints on some inexhaustible goods would implicate other constitutional values that are protected by other provisions, such as the right to travel (for roads) ${ }^{263}$ and the Article IV Privileges and Immunities Clause (for courts). ${ }^{264}$ Thus, while discriminatory restraints on non-resident usage in times of severe congestion might not offend the Dormant Commerce Clause, political and other constitutional constraints would appropriately prevent

worsen traffic congestion, reduce highway safety, and/or, at a minimum, impose additional wear and tear on the roadway. But these costs are qualitatively different from and less important than the denial of access altogether. A state has a legitimate interest in ensuring that its citizens may use such goods; it does not have an interest in ensuring that they can use them free of any and all interference from outsiders. Thus, for example, had South Dakota produced sufficient cement to satisfy in-state and out-of-state demand, it could not have continued to ban purchases by non-residents just to keep the customer service lines at the plant short.

262 Coenen, supra note 9, at 446-47; Varat, supra note 9, at 531.

263 Crandall v. Nevada, 73 U.S. 35 (1867).

264 Supreme Court of New Hampshire v. Piper, 470 U.S. 274 (1985); see also Regan, supra note 8, at 1200 (endorsing this view). 
states from imposing discriminatory restraints on non-resident use of many of these goods or services.

\section{CONCLUSION}

The investment capture model draws a clear line between state measures that regulate private commercial transactions and state measures that return taxpayer-funded goods or services to state citizens. According to this model, discriminatory subsidies, but not discriminatory tax exemptions or credits, are permissible. Likewise, state preferences for citizens in purchasing private goods for state use or selling state assets for private use are generally permissible, but not when natural resources are at stake or when the state possesses a legal or natural monopoly. Lastly, the validity of downstream restraints depends on whether the restraint serves to channel a state-funded subsidy to state residents or rather merely attempts to leverage state market power to require the private subsidization of such residents.

More fundamentally, the investment capture model provides an analytical platform for harmonizing the constitutional commitments to interstate equality and state autonomy. The Dormant Commerce Clause requires states to treat residents and non-residents alike so as to foster national economic union, while rudimentary notions of states as autonomous political communities suggest that states may prefer their own citizens over non-residents in some circumstances. By focusing the inquiry on whether state citizens have a special claim of entitlement to the particular good or service at issue that can only be vindicated through discriminatory access, the investment capture model gives due regard to both values. State citizens have a special claim upon those goods and services that they have created-but only those goods and services. 